\title{
A Poetics of Sisterly Affect in the Brothers Song and in Other Songs of Sappho*
}

\author{
Gregory Nagy
}

The Brothers Song and other new papyrus texts, including the first stanza of what is now known as the Kypris Song, reveal some heretofore missing pieces of the poetic personality whom we know as Sappho. ${ }^{1}$ In what I have to say here about this personality, I concentrate on the identity of Sappho as sister.

My approach builds on my previous publications about not only Sappho but also Alcaeus. ${ }^{2}$ My general argument in all these publications is that we can see the personalities of Sappho and Alcaeus come to life only if we view them as poetic creations of their songs. To say it another way, the songs of Sappho and Alcaeus were meant to be heard by the public who did hear them. They were not meant for private readers. And, in the case of compositions like the Brothers song and the Kypris Song, my specific argument is that the expressions of sisterly affect in such songs were sure to delight the listening public.

But what exactly would be so delightful about songs expressing an aristocratic woman's tormented feelings about a brother who squandered his family's wealth on a courtesan in Egypt? That is what her brother named Charaxos seems to have done, as we learn from a variety of ancient sources, starting with Herodotus (2.134-135). So, where is the delight here? In attempting to answer such a question, I focus on the mixed feelings of the sister, as expressed by the poetics of Sappho.

* This paper is a shortened version of what is published on the website of the Center for Hellenic Studies: http://nrs.harvard.edu/urn-3:hlnc.essay:NagyG.A_Poetics_of_Sisterly_Affect.2015.

1 The relevant texts have been published by Obbink (2014b) and Burris, Fish, and Obbink (2014) and re-edited by Obbink, ch. 1, this volume.

2 Esp. Nagy (2007b).

(C) GREGORY NAGY, 2016 | DOI: 10.1163/9789004314832_023

This is an open access chapter distributed under the terms of the Creative Commons Attribution-

Noncommercial 3.o Unported (CC-BY-NC 3.0) License. 


\section{Poetic Expressions of Mixed Feelings}

I start with the first three stanzas of fr. 5.1-11 of Sappho:

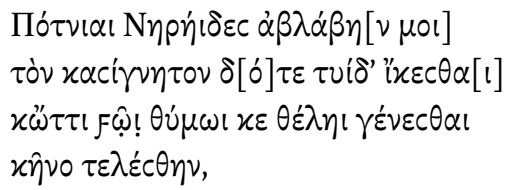

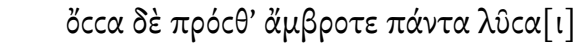

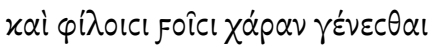

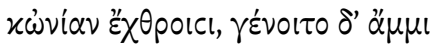
$\mu \eta \delta \alpha^{\prime} \mu \alpha \mu \eta \delta^{\prime}$ हां

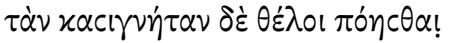

$10 \quad[\mu \dot{\varepsilon}] c \delta 0 v o c \tau i \mu \alpha c,[\delta v] i \alpha \nu \delta \dot{\varepsilon} \lambda v_{\gamma} \rho \alpha \nu$ $[\ldots]$...

O Queen Nereids, unharmed (ablabes) may my brother, please grant it, arrive to me here (tuide), and whatever thing he wants in his heart (thymos) to happen, let that thing be fulfilled (telesthen).

5 And however many mistakes he made in the past, undo them all. Let him become a joy (chara) to those who are near-and-dear (philoi) to him, and let him be a pain (onia) to those who are enemies (echthroi). As for us, may we have no enemies, not a single one.

But may he wish to make his sister (kasigneta) worthy of more honor (tima). The catastrophic (lygra) pain (onia) ... in the past, he was feeling sorrow (acheuon) ...

Here in fragment 5 , the loving sister is expressing a wish that her errant brother should become a chara or 'joy' to her loved ones (6), not an onia or 'pain' (7) — a pain that is then described as lygra 'catastrophic' (10). ${ }^{3}$ It should be the

3 It is possible, of course, that [jo]iav ... $\lambda \dot{\gamma} \gamma p \alpha \nu$ is a genitive plural, not an accusative singular. 
other way around, she is saying, so that the family will have the joy—while the enemies will have the pain. But the family itself should have no enemies at allnor any pain, as expressed twice by the noun onia (7 and 10).

Later on in fr. 5 , the speaking persona of Sappho turns to Aphrodite, address-

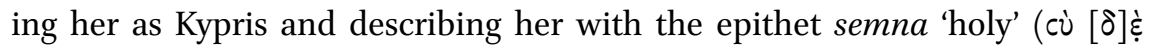
Kí $\tilde{[}[\rho] ! \sigma[\varepsilon \dot{\varepsilon} \mu] \nu, 18)$. Although the fragmentary state of the papyrus here prevents us from seeing the full context, it is clear that the sister is praying to the goddess to prevent further misfortune from happening to her brother, who 'in the past was feeling sorrow (acheuon)' $\left(\pi\left[\alpha^{\prime}\right] \rho \circ \theta^{\prime} \alpha \chi \varepsilon v^{\prime} \omega \nu, 11\right)$.

But the pain that torments the family because of the brother's misfortunes is not the only kind of torment we find in the poetics of Sappho. The same word onia 'pain' that refers to the torment experienced by the family of Sappho refers also to the torment of erotic love experienced by Sappho herself. In fr. 1.3-4 of Sappho, her speaking persona prays to Aphrodite to release her from such

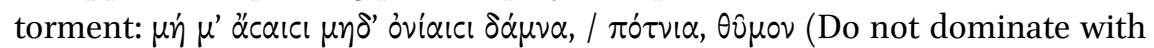
hurts [asai] and pains [oniai], / O Queen, my heart [thymos]).

Similarly in the first six lines of the Kypris Song, the speaking persona of Sappho once again turns to Aphrodite, praying that the goddess may release her from the torment of erotic love:

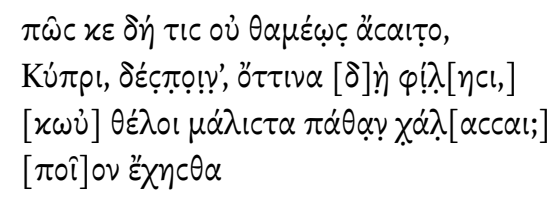

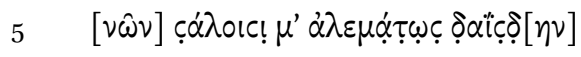

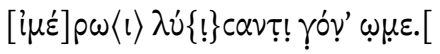

How can someone not be hurt (= asasthai, verb of the noun asa 'hurt') over and over again,

O Queen Kypris (Aphrodite), whenever one loves (philein) whatever person

and wishes very much not to let go of the passion?

(What kind of purpose) do you have

(in mind), uncaringly rending me apart

in my (desire) as my knees buckle?

The ending of this song was already known before the discovery of the new supplements for the beginning as I just quoted it. At this ending, we find the 
persona of Sappho declaring the poetics of her own self-awareness: है $\gamma \omega \omega \delta^{\prime}$ ' है $\mu^{\prime}$

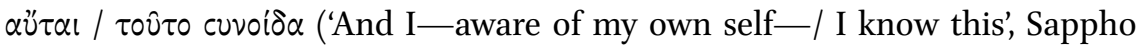
fr. 26.11-12 = Kypris Song, lines 11-12).

Such self-awareness as we find it at work in the songs of Sappho brings me back to the question I was asking from the start: what exactly is so delightful about songs expressing an aristocratic woman's tormented feelings about a brother who squandered his family's wealth on a courtesan in Egypt? I think that the answer to this question does in fact have to do with the delight of sensing that a woman's veiled self-awareness about her own feelings is making a connection here with an unveiled love story-about an upper-class man's self-destructive affair with a lower-class woman whose charms he finds utterly irresistible.

The songs of Sappho reveal an awareness of two kinds of torment. First, there is the torment experienced by a whole family in fearing a disgraceful loss of wealth and prestige. But then there is also the torment—and the delight—of a passionate love affair. This second kind of torment is experienced not only by the brother of Sappho but also by Sappho herself. The song-making of Sappho reveals here not only an awareness but also a self-awareness. And here is a special delight for the hearer of Sappho's songs - to hear about the torment of her own passionate loves.

The poetic language that expresses this torment - this onia and this asaenvelops both the errant brother and the anxious sister. Both are afflicted by the torment — and the delight—of passionate love. And this delight can be experienced by all who hear the songs of Sappho. Among these hearers, as we will see, is Herodotus himself.

Before I proceed to Herodotus, however, I am aware that I will first have to explain why I speak here of torment and delight in referring to the love story of Sappho's brother. I am thinking of Act 1 of La traviata, a romantic opera composed by Giuseppe Verdi (first performed in 1853), where the two lovers Alfredo and Violetta sing to each other about their passionate love affair. Both lovers express this love as a 'torment and delight', croce e delizia. Then, in Act 2, the father of Alfredo intervenes, confronting Violetta by singing to her an aria of his own. In this aria, the father expresses his own form of torment: how he fears that the reputation of his unmarried daughter, the sister of Alfredo, will be destroyed by the news of her brother's love affair. Here I ask myself a question. Suppose there existed an aria sung by the aristocratic sister herself: what feelings would she express? Perhaps, at first, she would be most aware of her own tormented fears about her reputation, which is now endangered by the love affair of her brother with a courtesan. But she could also be aware of the torment caused by passionate love—if she had experienced it herself. And 
she could even be aware of the delight. Without pushing an analogy too far, I reconstruct here the croce e delizia of a woman's own passionate loves-as expressed most forcefully in the veiled but self-aware songs of Sappho. That said, I can now concentrate on the delight of hearing songs about the torment caused by such passionate love.

\section{Starting with Herodotus}

I have already mentioned the passage in Herodotus (2.134-135) where he refers to the love affair of Charaxos, brother of Sappho, with a courtesan who lived in Egypt. The historian adds that Sappho scolded Charaxos-or the courtesanfor this affair, and that the scolding was done by way of melos 'song': 'Sappho scolded (kata-kertomein) him (or her) in many ways by way of her singing

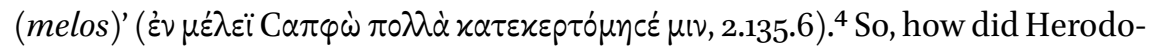
tus know about such songs of Sappho? I will be arguing that he himself could have heard such songs being sung - and was eager to show off his appreciation of the songs-but, before I can undertake such an argument, I will need to consider the possible occasions for someone like Herodotus to listen to such singing. And, even before that, I will need to consider the original occasions for singing the songs of Sappho.

In order to engage in such considerations, I will now examine the problem of reception in analyzing the songs of Sappho. An ideal place to start is a formulation by Dirk Obbink, who writes: 'The recorded reception of Sappho begins with Herodotus. ${ }^{5}$ I propose to build on this most helpful formulation by highlighting a qualification noted already by Obbink. The fact is, the text of Herodotus shows the first recorded case of reception. But the reception of Sappho can be reconstructed further back in time-back to earlier phases of reception. It can even be reconstructed all the way back to its original phases. The reception of Sappho, as I will now argue, goes back to the original creation of the songs attributed to her. And a similar formulation applies to the reception of Alcaeus. When I say 'original creation' here, I mean simply the earliest attested phase of the relevant songmaking. In terms of such an earliest phase, I will argue, the reception of songs attributed to Sappho and Alcaeus is already at work in the overall tradition of composing and performing such songs.

4 Ferrari (2014) 10 argues that the $\mu$ iv here refers to the courtesan, not the brother. See also Obbink (2014b) 41.

5 Obbink (2014b) 32 . 


\section{Viewing Diachronically the Reception and the Transmission of Sappho and Alcaeus}

I said already in my introduction that we can see the personalities of Sappho and Alcaeus come to life only if we view them as poetic creations that are shaped by their songs. But now I argue further that this view needs to be diachronic as well as synchronic. Here I continue a line of argumentation that I have been developing in all my previous publications about Sappho and Alcaeus. ${ }^{6}$ In using the term diachronic, I am applying the formulation of Ferdinand de Saussure concerning language as a system. As Saussure explains, a synchronic approach views a current phase of a system while a diachronic approach views different phases in the evolution of that given system. ${ }^{7}$ In the case of the poetic language represented by Sappho and Alcaeus, as also in even earlier cases represented by the likes of Hesiod and Archilochus, a diachronic approach involves not two but four aspects of poetic creation: there is not only composition and performance but also reception and even transmission. ${ }^{8}$

In any poetic system that depends on the performance of a given composition, the reception and the transmission of such a composition can be viewed in terms of a process that I describe as recomposition-in-performance. In terms of such a process, a reperformed composer can even become a recomposed performer. ${ }^{9}$ Here is what I mean. In the first place, the performer of a reperformance does not have to be the same person as an earlier performer, who can be viewed as the original composer. Still, such a performer of a reperformance can persist in appropriating to himself or herself the persona of the earlier performer - even if the historical circumstances of performance have changed. But then, in the process of recomposition-in-performance, even the persona of the performer can change over time, becoming different from the persona of the notionally original composer, and the differences in personality can be all the more pronounced if the venue of performance changes. That is how the persona of a reperformed composer can become recomposed in an

6 Esp. Nagy (2007b).

7 Saussure (1916) 117 .

8 On the four factors of composition, performance, reception, and transmission in the case of the poetry attributed to Hesiod, see Nagy (2009a). For similar arguments applied in the case of the poetry attributed to Archilochus, see Nagy (2008). More on the concept of reception in Nagy (2008/2009) ch. 2 §277.

9 Nagy (1996) 6 o. 
ongoing process of recomposition-in-performance. And that is how the reperformed composer can become the recomposed performer.

This formulation, as I have just summarized it, applies to the poetic personalities of Sappho and Alcaeus, as I have argued at length in my previous publications. ${ }^{10}$ In the context of reperformances in different times and in different places, the songs of Sappho and Alcaeus could become recomposed-inperformance, and their personae could thus become recomposed as well. That is how Sappho and Alcaeus, as reperformed composers, could become recomposed performers. And that is what I meant when I said, from the start, that Sappho and Alcaeus can be viewed as poetic creations of their own songs.

Here I return to Herodotus. In his era, dated to the second half of the fifth century вСЕ, the poetic personalities of Sappho and Alcaeus were already significantly different from what they had been in earlier times. In the contexts where Herodotus refers to Sappho (2.135.1 and 6) and to Alcaeus (5.95.1-2) as also to other comparable poetic figures such as Anacreon (3.121.1) - we can see in each case that these figures were by now viewed as poets who created monodic songs. Such songs, in the era of Herodotus, were performed solo, and there existed primarily two kinds of venue. On the one hand, there were amateur monodic performances at private symposia, while, on the other hand, there were professional monodic performances at public concerts, the most prestigious of which were the competitions of singing self-accompanied by a string-instrument at the Athenian festival of the Panathenaia.

What I just said is a most compressed formulation of a lengthy argument that I developed in a study entitled 'Did Sappho and Alcaeus ever meet?', where I analyzed diachronically the reception and the transmission of songs attributed to Sappho and Alcaeus. ${ }^{11}$ In terms of this argument, the poetic personalities of both Sappho and Alcaeus were actually reshaped in the historical contexts of the two venues that I have just highlighted for the era of Herodotus, namely, (1) private symposia, and (2) public concerts. In these contexts, especially as we see them take shape in Athens during the fifth century вСE, the songs originally attributed to Sappho and Alcaeus would be reperformed by performers who could re-enact the personae of Sappho and Alcaeus themselves, but, in the process of reperformance, these personae could be recomposed. That is how Sappho and Alcaeus could become recomposed performers. In the process of recomposition-in-performance, their poetic personalities could be recomposed by sympotic and concertizing performers, and, in this way, Sappho and

\footnotetext{
10 Nagy (1990), (1993), (1994-1995), (1996), (2004), (2007a), (2007b), (2009c).

11 Nagy $(2007 \mathrm{~b})$.
} 
Alcaeus themselves could be re-imagined as sympotic and concertizing performers in their own right. ${ }^{12}$

At a later point, I will offer further arguments to back up this formulation. For now, however, we have to deal with a more important question: how were Sappho and Alcaeus imagined before they became re-imagined as sympotic and concertizing performers? The answer is twofold. In the case of Sappho, as I have been arguing since 1990, she had been previously a choral personality, that is, someone who performs in a singing and dancing ensemble known as a choros or 'chorus'. ${ }^{3}$ In the case of Alcaeus, on the other hand, he had been previously a comastic personality, that is, someone who performs in a singing and dancing and wine-drinking ensemble known as a komos or 'group of male revelers'. And secondarily, Alcaeus could also be a choral personality in his own right, like Sappho herself: a likely example is fr. 34 of Alcaeus, which is a prayer to Castor and Pollux.

\section{Distinguishing between Sympotic and Comastic Occasions}

I will now trace the ramifications of the distinction I am making between sympotic and comastic occasions. ${ }^{14}$ The term sympotic, as I use it here, is meant to be generalizing. It can refer to any grouping of male drinkers who attend a symposium. I say generalizing because we can find no single criterion for defining a group of male drinkers who attended any ancient Greek symposium. By contrast, my term comastic is meant to be more specific, in the sense that male drinkers who were grouped together in a komos must have felt bound to each other by special ties that bind: such a grouping, as it becomes evident in the poetic language of Alcaeus, consisted of men who were etairoi or 'comrades' to each other. ${ }^{15}$

Another distinction between sympotic and comastic occasions is the fact that a sympotic song, as we see it attested in the era of Herodotus and thereafter, was ordinarily performed by a solo singer, in monodic form, to the accompa-

12 Nagy (2007b); see also Bierl (2010). On citharodic traditions in performing the songs of Sappho, see Nagy (2011b) 155-158, following Power (2010) 258-263.

13 I first used this expression 'choral personality' in Nagy (1990a) 370, with reference to Calame (1977) 367-377 (also 126-127). See also Lardinois (1996) and the remarks of Calame (2009) 5. Also Ferrari (2014) 17.

14 There is an earlier formulation in Nagy $(2007 \mathrm{~b}) 212$.

15 Nagy (2004), with special reference to the insights of Rösler (1980) and (1985) concerning the poetics of etairoi 'comrades'. 
niment of a wind- or a string-instrument, whereas a comastic song would have been performed by a group that could both sing and dance. This is not to say that an individuated singer-or a succession of individual singers-could not dominate the overall group performance of a komos. But I do insist that any exclusively solo performance of a song would have been incompatible with the mentality of a group that sings and dances in a komos. ${ }^{16}$

\section{Distinguishing between Sympotic and Choral Occasions}

A similar distinction applies in the case of sympotic and choral occasions. A sympotic song, I repeat, was ordinarily performed by a solo singer, in monodic form, to the accompaniment of a wind- or a string-instrument. By contrast, a choral song was performed by a group, known as the choros or 'chorus', which both sang and danced to the accompaniment of a wind- or a stringinstrument.

Here too in the case of the choros, as in the case of the komos, I am not saying that an individuated singer-or a succession of individual singers-could not dominate the overall group performance. But I do insist, once again, that any exclusively solo performance of a song would have been incompatible with the mentality of a group that sings and dances. Such a group, I maintain, was the choros. $^{17}$

In view of these distinctions between monodic and non-monodic performance, I reconstruct a split between the later personae of Sappho and Alcaeus, who were both pictured as monodic singers, and the earlier personae, who need to be viewed in the historical context of group performances. I have already described these earlier personae as a choral Sappho and as a comastic Alcaeus, and I have left the door open for a choral Alcaeus as well. But before I can say anything more about such choral and comastic personae, I first need to explore the historical circumstances of the earliest attested venue where such personae could actually come to life.

\footnotetext{
16 Nagy (2007b) 212, 218-219, 230, 240, 242.

$17 \quad \operatorname{Nagy}(2007 \mathrm{~b}) 215^{-216 .}$
} 


\section{The Earliest Known Venue for Sappho and Alcaeus}

From a diachronic point of view, the earliest attested venue for performing the songs of Sappho and Alcaeus can be located in a space known in ancient times as Messon, now called Mesa, which figured as a politically neutral 'middle ground' for the entire island of Lesbos (see Fig. 8.1, p. 199). The basic arguments proving this localization were published in a 1960 article by Louis Robert, ${ }^{18}$ whose work has been foundational for my own diachronic analysis of the poetic venues for both Sappho and Alcaeus. ${ }^{19}$

The published reactions to the work of Robert have been thoroughly reviewed and tested in a 2010 article by Stefano Caciagli, whose own conclusions validate most of the original arguments advanced fifty years earlier by Robert. ${ }^{20}$ Although he does not say so, the conclusions offered by Caciagli also validate — for the most part—what I had argued in a 1993 article entitled 'Alcaeus in sacred space', published in the Festschrift for Bruno Gentili. ${ }^{21}$ In that article, I supported the argument, originated by Robert, that the poetry of Sappho and Alcaeus actually refers to Messon-as that place existed at a time that corresponds to the traditional dating of these poetic figures, around 600 BCE. $^{22}$

I start with the references to Messon in fr. 129 and fr. 13ob of Alcaeus. The name of the place is not mentioned, but the identification is clear. The songs refer to the place as a temenos 'precinct' ( $\tau \dot{\varepsilon} \mu \varepsilon v o c$, fr. 129.2 and 130b.13), pictured

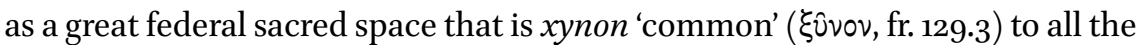
people of the island of Lesbos. The precinct is sacred to three divinities: they are Zeus, 'the Aeolian goddess', and Dionysus (fr. 129.5-9). As we will now see,

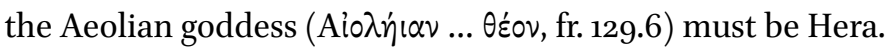

I highlight already here another relevant reference, this one in fr. 130a of Alcaeus, to the same precinct: it is called the teichos basileion 'the queenly wall' ( $\tau \varepsilon i x o c \beta a c i \lambda \eta ı v$, line 15), glossed as 'Hera's wall' in a scholion written next to the text ( $\tau \dot{0} \tau \hat{\eta} c$ "Hpac). I translate basileion here as 'queenly', not 'kingly', in

18 Robert (196ob). His article is prominently featured in a collection of influential French research papers translated into English, edited by Loraux, Nagy, and Slatkin (2001) 240248. In the first footnote there, grecques needs to be corrected to anciennes.

See esp. Nagy (1993), (1994-1995), (2004), (2007a), (2007b).

20 Caciagli (2010) 228, 238. See now also Liberman (1999) I 61 n. 127.

21 Nagy (1993); this article is not mentioned by Caciagli (2010), who cites only one of my relevant works on Sappho and Alcaeus, Nagy $(2007 \mathrm{~b})$. At a later point, I will have to disagree slightly with what he says I argue in Nagy (2007b).

Nagy (1993); I elaborate further in Nagy (2007b). 
the light of what we read in the newly-found Brothers Song of Sappho: the speaking Sappho in this song says that she needs to be sent off to pray to

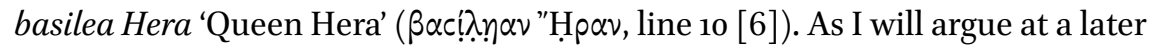
point, the queenly status of the goddess Hera subsumes even the kingly status of her consort, the god Zeus, who is described as the basileus Olympo 'king of Olympus' in the Brothers Song ( $\beta \alpha c^{\prime} \lambda \varepsilon v c^{\prime} \mathrm{O} \lambda \nu \dot{\nu} \mu \omega \omega$, line 17 [13]).

I continue my argument that the queenly residence of the goddess Hera must be the precinct at Messon. In the Brothers Song, it is in this precinct that Sappho will pray for the safe return of her brother Charaxos from a sea voyage. Even as she pictures herself as praying, she expresses the hope that the brother is sailing his way back home (lines 11-12 [7-8]). Where is home? It is a place that is signaled by the deictic pronoun tuide 'here' in the words of the Brothers Song

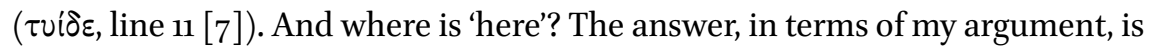
that this place 'here' is Messon.

Sappho will not be praying alone to Hera. She will be part of a procession that must be sent off to the precinct of the goddess, as we can see from the expression pempen eme 'send me' in the Brothers Song ( $\pi \dot{\varepsilon} \mu \pi \eta \nu$ है $\mu \varepsilon$, line 9 [5]), which I argue refers to the sending of not one person in this case: rather, it is the sending of a procession, the classical Greek word for which would be pompe. Not only will Sappho be a part of a procession; she will also have the leading part, as indicated by the focus on 'me' in the expression pempen eme 'send me' ( $\pi \dot{\varepsilon} \mu \pi \eta \nu$ है $\mu \varepsilon$, again, line $9[5])$.

Once the sacred procession reaches the precinct of the goddess, as we will now see, the processing ensemble will transform itself into a chorus of singing and dancing women who are charged with the sacred imperative of supplicat-

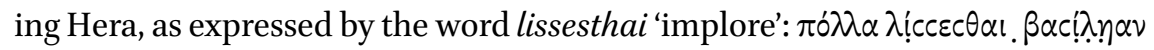
"Hpav ('to implore [lissesthai] Queen [basilea] Hera over and over again', Sappho Brothers Song, line 10 [6]). In fragment 1.1-7 of Sappho, we see a comparable situation where Sappho is supplicating a goddess-this time, it is Aphrodite—and again the word for the ritual action that I translate as 'implore' is lissesthai (2):

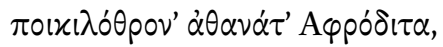

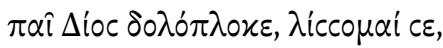
$\mu \eta \mu^{\prime} \alpha \ddot{\alpha} c \alpha I c l \mu \eta \delta^{\prime}$ óvíalcl $\delta \dot{\alpha} \mu \nu \alpha$, $\pi o ́ \tau v i \alpha, \theta \hat{\jmath} \mu \circ v$,

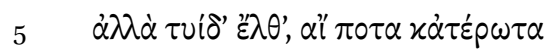

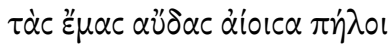

हैं $\chi \lambda \cup \varepsilon c, \ldots$ 
You with pattern-woven flowers, immortal Aphrodite, child of Zeus, weaver of wiles, I implore (lissomai) you, do not dominate with hurts (asai) and pains (oniai),

O Queen, my heart (thymos).

But come here (tuide), if ever at any other time, hearing my voice from afar, you heeded me ...

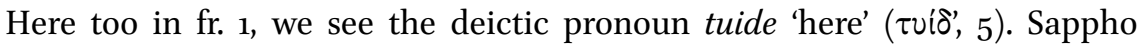
implores the goddess Aphrodite to come tuide 'here' to the place where she is praying, just as she will implore the goddess Hera to bring back her brother tuide 'here' to the place where she is praying in the Brothers Song ( $\tau$ vi $\delta \varepsilon$, line 11 [7]).

\section{Processing to the Precinct of Hera}

A moment ago, I started to argue that Sappho's prayer to Hera in the Brothers Song can be seen in the overall context of a sacred procession that proceeds to the precinct of Hera, at which place the processing ensemble will transform itself into a chorus of singing and dancing women who are charged with the sacred imperative of supplicating the goddess. As I will now argue further, the procession is in fact already a chorus in the making. Pursuing this argument, I now cite a parallel kind of event that took place at the precinct of Hera-not the one at Lesbos but the one near the city of Argos. I start by quoting a description of the pompe 'procession' of the Hekatombaia, which was the Argive name for the seasonally recurring festival of the goddess Hera at Argos, from a scholion to Pindar Ol. 7.152d.1:

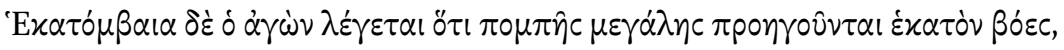
oîc vó

This festival-of-competitions (agon) is called Hekatombaia because one hundred cattle are led forth in a grand procession ( pompe), and their meat is divided by customary law among all the citizens of the city.

The name of this festival, Hekatombaia, refers to a hekatombe 'hecatomb', which is the sacrificial slaughtering of one hundred cattle in honor of Hera. And the procession that led up to this sacrifice in honor of the goddess at her festival 
in Argos culminated in a choral performance of Argive girls who participated in that procession. This culminating ritual event can be reconstructed on the basis of what we read in the Electra of Euripides. ${ }^{23}$ The role of the chorus that is singing and dancing in this drama is twofold: the performers in the chorus here represent not only the girls of Argos in the mythical past but also the girls of Argos who participated in the rituals of the seasonally recurring festival of Hera in the historical present of the drama composed by Euripides. In the Electra of Euripides, the male Athenian chorus of his drama is representing a female Argive chorus participating in a contemporary version of Hera's festival, and this female Argive chorus is in turn representing their prototypical counterparts in the mythical past. Already back then, in that mythical past, a chorus of Argive girls is participating in the festival of Hera. In the Electra of Euripides, there are explicit references to the upcoming choral performance of these mythical girls at Hera's festival. ${ }^{24}$ And the festival itself, as we will now see, is explicitly called a thysia, meaning literally 'sacrifice' (172). Here is the way the word is used in the song that is sung and danced by the chorus of Argive girls in Eur. El. 167-174:

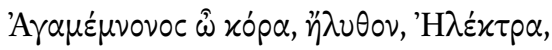

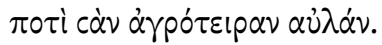

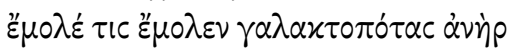

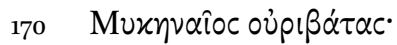

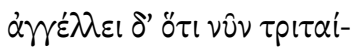

av xapúccovelv $\theta u c i a v$

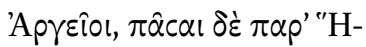

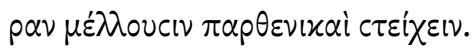

O Electra, daughter of Agamemnon, I (= the chorus, speaking as a singular 'I') have arrived / at your rustic courtyard. / He has come, a milk-drinking man, he has come,/ a Mycenaean, one whose steps lead over the mountains. / He announces that, on the third day from now, / a sacrifice (thysia) is proclaimed / by the Argives, and that all the girls (parthenikai) to Hera must proceed (steichein).

23 What follows here recapitulates what I say in Nagy (2015b) ch. 4 § 149-15o concerning relevant passages in the Electra of Euripides.

24 For more on the self-representation of the chorus as chorus in the Electra of Euripides, see Baur (1997). 
The word thysia here (172) is referring to the ritual centerpiece of the festival, which is the hecatomb, that is, the sacrifice of one hundred cattle. But the same word thysia is also referring, by way of metonymy, to the entire festival. Each and every girl from each and every part of the Argive world must steichein 'proceed' to Hera-that is, to the festival of Hera. Each girl personally must make the mental act of proceeding to the goddess. Each girl collectively must join in, that is, join the grand procession that will lead to the precinct of the goddess, where the hundred cattle will be slaughtered in ritual sacrifice. We see here a religious mentality that shapes the idea of the pompe 'procession' as we just saw it described in the scholia for Pindar Olympian 7 .

It is this procession of girls from Argos that leads to the festival proclaimed by the Argives at line 172 of the Electra. The relevant words, to repeat, are pompe for 'procession' and thysia for 'sacrifice'. And the word thysia, as we have just seen, is a metonymic way of saying 'festival'. After the procession reaches the precinct of Argive Hera, what happens next is the sacrifice of one hundred cattle, followed by festive celebrations. And these festivities will include the choral singing and dancing performed by the girls of Argos. So, the pompe 'procession' extends into the choral performance, by way of the sacrifice that will take place after the entry of the procession into the precinct. We see here a validation of the formula proposed by Anton Bierl concerning processions as represented in Greek theater: he argues that any procession that leads into a choral performance will thereby become part of the choral performance. ${ }^{25}$ There is a metonymy at work here. ${ }^{26}$ Further, in the case of the drama composed by Euripides, Electra is potentially the prima donna who will lead the procession that will be transformed into the choral performance of the Argive girls when they reach the precinct of Hera. In fact, the word that Electra herself uses in referring to the upcoming performance of the girls at the precinct is choros (Xopoúc, 178). For the moment, though, Electra declines the 'invitation to the dance' $(178-180) \cdot{ }^{27}$

\section{A Festival for Hera at Lesbos}

Similarly in the Brothers Song of Sappho, I propose that Sappho herself is potentially the prima donna who must lead a procession to the precinct of

\footnotetext{
$25 \operatorname{Bierl}(2009) 57$ n. 152, 107, 272-273, 284, 294-295, 318-319. See also Bierl (2011c).

$26 \quad$ Nagy (2015b) ch. 4 §150.

27 For more on the Electra of Euripides, see Zeitlin (1970).
} 
Hera at Lesbos, and, once this precinct is reached, the procession will then be transformed into a choral performance of girls celebrating a festival that climaxes in the sacrifice of one hundred cattle to the goddess. And the leader of this choral performance must be Sappho herself, just as she must be the leader of the procession that leads up to the performance.

Such a role for Sappho, as a prima donna who leads the procession to the precinct of Hera and who then leads a chorus of girls who sing and dance there to celebrate a festival held in honor of the goddess, is based on a precedent, as it were, that goes back to the age of heroes. To explain such a precedent, I start with a point of comparison involving the traditions of Argos.

In the text of a fictional narrative attributed to Dictys of Crete, we find a detail that can be reconstructed as part of a local Argive myth concerning the precinct of Hera at Argos. According to the myth as retold by the fictional Dictys (1.16), it was in this precinct that the hero Agamemnon was chosen to lead the expedition to Troy. ${ }^{28}$ Such a formal beginning that takes place at the precinct of Hera, where the festival of the goddess was celebrated by the Argives, must have been a sacrifice, which can be identified with the seasonally recurring thysia at the festival of Hera in Argos. Here I must highlight again what I already highlighted in the text I quoted from Euripides: the word thysia refers metonymically to the festival itself, though its basic meaning is 'sacrifice'.

This detail about the precinct of Hera at Argos is a most valuable piece of comparative evidence, since it helps us understand what happened once upon a time in the corresponding precinct of Hera at Lesbos-not in the age of Sappho but in the heroic age. As we are about to see, there existed a local myth about what happened there in that precinct, and this myth functioned as an aetiology for a festival - and for the ritual centerpiece of that festival, which was a sacrifice of one hundred cattle.

I will postpone until later my working definition of aetiology and, for the moment, I will concentrate instead on the festival that is being aetiologized. I will show that this festival, celebrated in honor of Hera at Lesbos, highlighted a sacrifice of one hundred cattle inside the precinct of the goddess. A reference to both the festival and the sacrifice, I argue, has been preserved in the Alexandrian lexicographical tradition, as represented by Hesychius. In the dictionary of Hesychius (v. 2 p. $65^{2}$ ed. Latte), we find the entry mesostrophoniai hemerai,

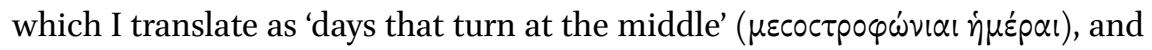
this entry is defined as follows: 'these are the days during which the people of

$28 \quad \operatorname{Nagy}(2009 / 2010) 294$. 
Lesbos arrange (epitelein) a thysia that is common (koine) to all of them' ( $\dot{\varepsilon} \vee$ aic

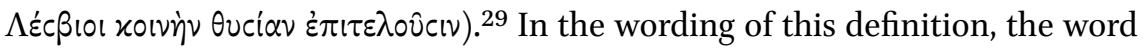
thysia refers not only to the sacrifice but also, metonymically, to the festival itself.

\section{The Festival in Fragment 17 of Sappho}

Fragment 17 of Sappho actually refers to a myth about this festival at Lesbos. The myth is telling about a time in the heroic age when the Atreïdai 'Sons of Atreus' - that is, Agamemnon and his brother Menelaus—-made arrangements for the institution of a festival of Hera to be celebrated inside her precinct at Lesbos after their victory at Troy. Here is the relevant text (fr. 17.1-16):

$$
\begin{aligned}
& \pi \lambda \alpha \dot{c} \operatorname{cov} \delta \eta \mu[\ldots . . . \text {. olc' } \alpha[\ldots . .] \omega
\end{aligned}
$$

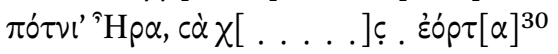

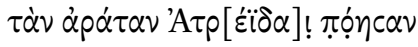

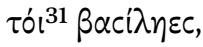

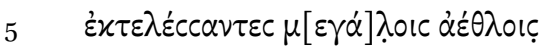

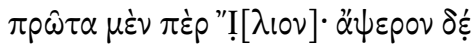

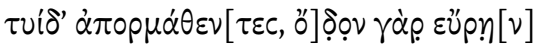

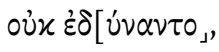

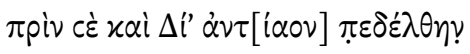

10

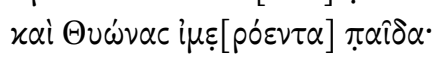

vôv $\delta \dot{\varepsilon} x[\alpha i \ldots . . . .].] \ldots \pi \dot{\eta} \eta \mu \varepsilon v$

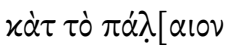

29 There may be a connection between the semantics of mesostrophoniai and Messon: see Robert (196ob) 303-304, also Pirenne-Delforge and Pironti (2014) 28 n. 13.

30 Ferrari (2014) 16 proposes to read ćóp $\tau[\alpha \nu]$, but this alternative reading does not affect my interpretation here.

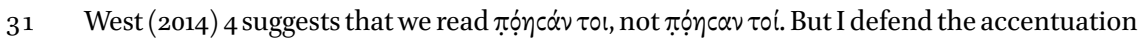
preserved in the new papyrus. As I will argue, we see here an emphatic use of the pronoun, 'for you', not an enclitic use. This reading ró (with the accute accent preserved in P. GC inv. 105 fr. 2) differs slightly from the reading $\tau$ 'ol as accepted by Obbink, ch. 1, this volume. I interpret the acute as a marker of a rise in the melodic contour, and such a rise here indicates an emphatic use of the pronoun. 
ärva xai xa. $[c .12$ ö] $] \lambda \lambda \circ c$

$\pi \alpha p \theta \dot{\varepsilon}[\nu \omega \nu c .12 \gamma] v \nu \alpha i x \omega \nu$

$15 \alpha \mu \varphi \mid c .[\ldots]$

$\mu \varepsilon \tau \rho^{\prime} \stackrel{\text { ọ̣ }}{\lambda}\left[0 \lambda v^{\prime} \gamma \alpha c\right] .{ }^{32}$

Close by, ...,

O Queen (potnia) Hera, ... your [...] festival (eorta),

which, vowed-in-prayer (arasthai), ${ }^{33}$ the Sons of Atreus did arrange

(poiein)

for you, kings that they were,

5 after first having completed great labors (aethloi),

around Troy, and, next (apseron),

after having set forth to come here (tuide), since finding the way was not possible for them

until they would approach you (Hera) and Zeus lord of suppliants

(antiaos)

and (Dionysus) the lovely son of Thyone.

And now we are arranging (poiein) [the festival],

in accordance with the ancient way $[. .$.

holy (agna) and [...] a throng (ochlos)

of girls (parthenoi) [...] and women (gynaikes)

15 on either side ...

the measured sound of ululation (ololyga).

Although the first line of fr. 17 here is too fragmentary to be understood for sure, the next line makes it clear that the persona of Sappho is praying to Hera herself, speaking to her about the eorta 'festival' (źóp $\tau[\alpha), 2$ ) that is being arranged in honor of the goddess. The speaking Sappho goes on to say that the festival that 'we' in the present are arranging ( $\pi$ ón $\mu \varepsilon v, 11)$, as 'we' offer supplications to Hera, is being arranged 'in accordance with the ancient way' ( $\chi \dot{\alpha} \tau \tau \dot{\alpha} \pi \dot{\alpha} \lambda[\alpha 10 \nu], 12$ ) of arranging the festival, just as the heroes of the past had arranged it ( $\pi$ ọ́ncav, 3). In these contexts, I am translating the word poiein 'make'

32 On this restoration, I follow Ferrari (2014) 18.

33 In the analysis that follows, I will fine-tune this translation 'vowed-in-prayer' for arata $(n)$, which is a verbal adjective of the verb arasthai 'pray'. 
in the specific sense of 'arrange', with reference to the observance of a ritual. I find in Thucydides (2.15.2) a striking parallel in wording: 'and the Athenians, continuing what he (= Theseus) started, even now arrange (poiein) for the goddess (= Athena), at public expense, the festival (heorte) named the Synoikia'

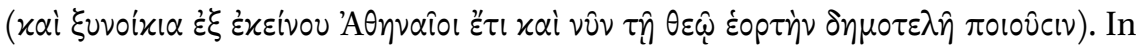
the case of the eorta 'festival' at Lesbos, the heroes who 'arranged' it were the Atreïdai or Sons of Atreus, that is to say, Agamemnon and Menelaus, and they made these arrangements primarily for the goddess Hera, who is indicated here

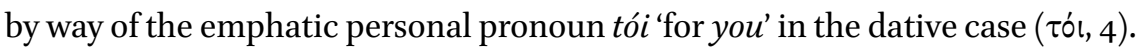
(Below, I will defend this reading tói 'for you', which is actually transmitted in the new papyrus fragment.) Similarly, in the wording of the passage I just cited from Thucydides, the seasonally recurring arrangements of the Athenian heorte 'festival' known as the Synoikia are being made 'for the goddess' in the dative case $(\tau \hat{\eta} \theta \varepsilon \hat{\omega})$.

So, what kind of a festival did the Sons of Atreus arrange 'for' Hera? To formulate an answer, I start with the word that describes the eorta 'festival' at line 2 of fr. 17: it is the verbal adjective aratos in the feminine gender, $\dot{\alpha} \alpha \dot{\alpha} \tau \alpha \nu$ (3), which I translate for the moment as 'vowed-in-prayer' and which is derived from the verb arasthai 'vow-in-prayer'. My initial translation of this adjective arata as 'vowed-in-prayer' is based on the Indo-European linguistic heritage of the verb arasthai and of its synonym euchesthai. Most relevant here is a chapter entitled 'The Vow' in a book by Emile Benveniste, Indo-European Language and Society, where the analysis focuses on Greek euchesthai and its Latin cognate, voverre. ${ }^{34}$ The Latin verb voverre can be translated as 'vow' in contexts where someone is praying to a divinity and asking for a favor to be granted, in return for which favor a vow is made to do something that is meant to gratify the divinity. Such a translation also applies in comparable contexts of the Greek verb euchesthai. So, when you make a vow in a prayer, as expressed by way of the word euchesthai, you are saying to a divinity that you will do or are doing or have done something in the hope that the divinity to whom you are praying will grant what you are wishing for. For a most pertinent example in the Iliad, I cite a situation where the hero Pandaros is being urged (misleadingly, by Athena in disguise) to make a vow-in-prayer as expressed by the verb euchesthai ( $\varepsilon \dot{v} \chi \varepsilon \circ, 4.101)$ : this hero, by way of making a vow-in-prayer to Apollo, would be vowing that he would perform an animal sacrifice (4.102) in the hope that the god would grant him what he is wishing for, which is a safe homecoming

34 Benveniste (1973) part 6, sub-part 4. For the online version of this chapter, see http://chs .harvard.edu/CHS/article/display/3967. 


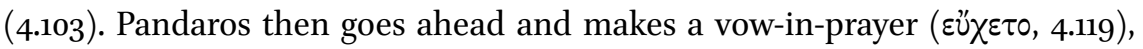
vowing that he will in fact perform an animal sacrifice (4.120) in hopes of a safe homecoming (4.121). So, as Benveniste says about the meaning of euchesthaiand his formulation applies also to the synonym arasthai- 'the "prayer" is not distinguished from the "vow": it is one and the same operation. ${ }^{35}$ Or, as I would prefer to say it, the wish-in-prayer is not distinguished from the vow-in-prayer. I can paraphrase in terms of the Latin noun votum, translated as 'vow', which is a derivative of the Latin verb voverre, translated as 'vow'. When you pray to a divinity, the word for what you vow to do is vottum, but the word for what you wish for is likewise vōtum. ${ }^{36}$ In the case of the hero Pandaros in the Homeric Iliad, his wish — and therefore his prayer-is a failure, since he will soon be killed on the battlefield (5.290-296).

Here I must stop to adjust the formulation of Benveniste. As Leonard Muellner has shown, the English translation 'vow' for such words as euchesthai works only in situations where the human who prays to a divinity is announcing an act that will happen in the future. ${ }^{37}$ But the fact is, the act of gratifying a divinity can happen in the present or even in the past. What you announce in prayer does not have to be a promise about the future: it can also be an announcement about the present or even about the past. ${ }^{38}$ So, the translation 'vow-in-prayer' for euchesthai-and for arasthai-does not cover the full range of meanings for these verbs. From here on, accordingly, I will translate these verbs simply as 'announce-in-prayer', not 'vow-in-prayer'. And I must emphasize that, in each case of an announcement-in-prayer, the other side of the coin is a wish-in-prayer.

With this background in place, I return to the noun eorta 'festival' at line 2 of fr. 17 of Sappho, and to the verbal adjective arata that describes this festival at line 3 ( $\dot{\alpha} \rho \dot{\alpha} \tau \alpha \nu)$. Now translating arata as 'announced-in-prayer', I interpret the wording here to mean that Agamemnon and Menelaus, the two Sons of Atreus, had once upon a time announced-in-prayer the celebration of the festival or eorta that is still being celebrated in Sappho's song. And, by virtue of making this announcement-in-prayer, these two heroes were simultaneously making a wish-in-prayer. So, what did they wish for? The wording makes it quite clear that their wish was to find the best way to make a safe homecoming, literally, 'to

35 Again, Benveniste (1973) part 6, sub-part 4.

$3^{6}$ In the light of this Indo-European semantic background, we can better understand the following attestation of the verb arasthai in the diction of Sappho: 'they wished (arasthai)

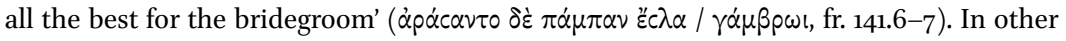
words, they wished-in-prayer that the best possible things should happen to the bridegroom.

37 Muellner (1976) 55-56.

38 For a survey of Homeric examples, see Muellner (1976) 36-37, 55-56. 


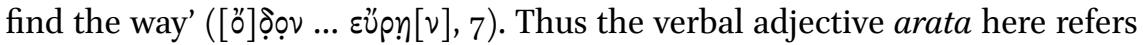
simultaneously to the festival that the heroes announced-in-prayer and to the safe homecoming that they wished-in-prayer.

Accordingly, I disagree with the idea that the adjective arata ( $\left.\alpha \alpha_{\alpha} \tau \alpha \nu\right)$ at

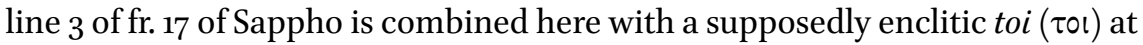
line 4 , as if the combination had meant 'wished by you', that is, by the goddess Hera. Such an idea is advocated by Martin West, who emends the wording

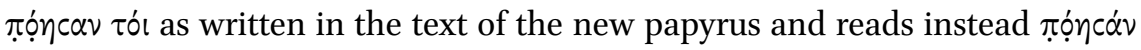
$\tau 0 .{ }^{39}$ And I defend the accentuation that is actually preserved in the new papyrus, tór. $^{40}$ As I will argue, we see here an emphatic use of the pronoun, 'for you', not an enclitic use. This non-enclitic and emphatic tói 'for you' (тóı) at line 4 goes with the verb poesan 'arranged' ( $\pi$ ọ́ncav) at line 3 , indicating that the Sons of Atreus arranged the festival for the goddess Hera.

Now I offer further support for my resisting the idea that the adjective arata

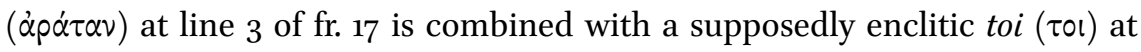
line 4. If we look at uses of the dative case in combination with this adjective, we can see that such a dative refers to the human who offers an announcementin-prayer, not to the divinity who might have wished to receive such a prayer. In Homeric diction, we can see situations where this adjective aratos describes what is wished for - or wished away - by way of an announcement-in-prayer. In positive contexts, for example, I cite the compound form poly-aretos in Odyssey 6.280 , with reference to a god whose coming is wished-for in prayer. ${ }^{41}$ And here is an even more telling example, where Eurykleia is narrating what she as the nurse of the infant Odysseus had once upon a time said to the boy hero's grandfather, Autolykos (Od. 19.403-404):

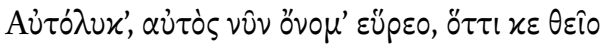

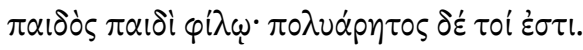

39 West (2014) 4; see also Ferrari (2014) 17.

40 The acute accent appears in the new P. GC inv. 105 fr. 2, but not in the older PSI 123 and P. Oxy. 1231; see the critical apparatus of Obbink, ch. 1, this volume.

41 In negative contexts where something is wished-away, not wished-for, the non-compound form aratos is more usual (as in Iliad 24.741); but poly-aratos too is attested in negative contexts (as in Theognis 819). Such uses of aratos, derived from arasthai, correspond to some specialized uses of euktos, derived from euchesthai 'pray', as we see in the gloss of Hesychius: $\dot{\alpha} \pi \dot{\alpha} \rho \alpha \tau o v \cdot \dot{\alpha} \pi \varepsilon u x \tau o ́ v$, where both forms refer to something to be wished away;

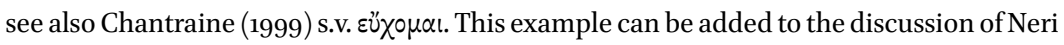
(2014) 15-16 regarding the attested uses of arasthai. 
Autolykos! You yourself must find a name, whatever name you give him, for the dear child of your child, since he is the one who has been very much wished-for (poly-aretos) by you (toi).

The dative toi here $(\tau 01,404)$ refers to the maternal grandfather himself, who had been very much wishing for a grandchild. As we can see most clearly from this Homeric example, the dative refers to the human who makes an announcement-in-prayer, not to the divinity who is offered that prayer.

I should add that, when a divinity actually grants something that is wished for in an announcement that is made in prayer, this granting of a wish does not come without an obligation to return the favor, as it were, in terms of the system of gift-giving that is inherent in any prayer. So, the thing that you wish for may have to be dedicated to the divinity who granted you the wish. Let us return to the example of poly-aretos in Odyssey 19.404: here we see that Odysseus, as the maternal grandchild that Autolykos had always wished for, will have to become, as soon as he is born, a devotee of the divinity who granted the wish to the grandfather. In this case, that divinity was Hermes, to whom Autolykos had offered sacrifices of sheep and goats (19.396-398).

In this example, we see most clearly a situation where the sacrifice that was announced in prayer was an event that happened in the past-not an event that was promised for the future. I emphasize here once again the importance of the fact that whatever you announce in prayer does not have to be a promise about the future: it can be, to repeat, an announcement about the present or even about the past. That is why, as I already argued, the translation 'vow-inprayer' for euchesthai and arasthai does not cover the full range of meanings for these verbs. And that is why I have substituted the translation 'announcein-prayer', the other side of which is 'wish-in-prayer'.

A moment ago, I used the expression return the favor in referring to the consequences of a situation where a divinity heeds a prayer offered by a human, thus doing a favor for the human. In such a situation, the human will feel obligated to return the favor. Conversely, as we will soon see, the divinity to whom a human prays is not obligated to heed a prayer. So, the divinity is not obligated to return the favor of, say, a sacrifice that is announced-in-prayer. The making of a sacrifice that you announce in prayer - whether that sacrifice takes place in the past, present, or future-does not guarantee that you will get your wish from the divinity to whom you are praying.

Applying these comparanda to fr. 17 of Sappho, let us consider again the

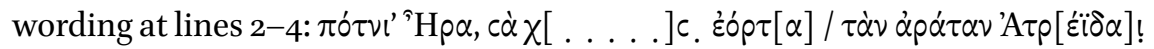

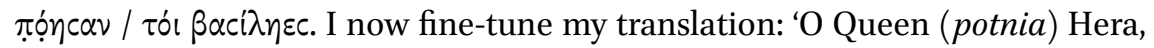
... your [...] festival (eorta), / which, announced-in-prayer (arasthai), the Sons 
of Atreus did arrange (poiein) / for you, kings that they were .... So, the eorta

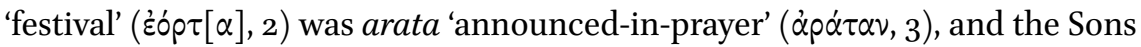
of Atreus 'arranged' it, poesan ( you' ( $\tau o ́ l, 4)$. This form tói, as I have argued, is non-enclitic and emphatic.

If, on the other hand, we were to accept West's interpretation, the text would

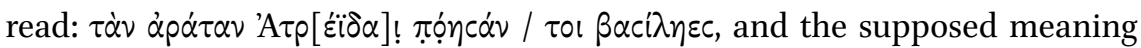
would be 'which (= the festival), wished by you (= Hera), the Sons of Atreus, kings, made'. As I argue, however, the interpretation 'wished by you', where the supposedly enclitic toi 'you' refers to a wish that is supposedly made by Hera, is unjustified. Also, it would be difficult or perhaps even impossible to justify the postponed word-order of such an enclitic toi.

For the moment, in any case, I prefer to follow the reading of the text as written in the new papyrus fragment. In terms of this reading, as we have seen, the use of poiein in the active voice $\left(\pi \operatorname{cop}_{\eta} c \alpha \nu, 3\right)$ means that the Sons of Atreus 'arranged' the festival 'for' the goddess Hera in the dative, that is, 'for you' ( $\tau$ '́, 4), and this syntactical construction corresponds to the use of the active voice of poiein that we already saw in the wording of Thucydides (2.15.2) regarding the festival 'for' the goddess Athena, likewise in the dative: 'and the Athenians, continuing what he (= Theseus) started, even now arrange (poiein) for the goddess (Athena), at public expense, the festival (heorte) named the Synoikia'

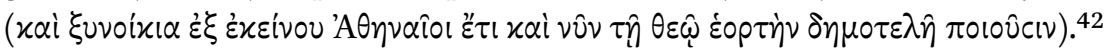

\section{A Sacrifice of one Hundred Cattle as the Centerpiece of the Festival for Hera}

As I reconstruct it, the seasonally recurring festival for Hera at Lesbos would have centered on a grand sacrifice, comparable to the sacrifice of one hundred cattle for the festival of Hera at Argos. I will argue that the centerpiece of the festival of Hera at Lesbos was a hecatomb, comparable to the centerpiece of the festival of Hera at Argos. And a word that suits the essence of such a festival is thysia, which as we have already seen means simultaneously 'sacrifice' and 'festival'. I repeat here the precious information we find in the dictionary of Hesychius, where the term mesostrophoniai hemerai, which I translated as 'days

42 This context of poiein in the active voice with heorte as direct object is I think different from contexts of poieisthai, in the middle voice, again with heorte as direct object, as in Hdt. 1.150.1 and Pl. Resp. 1.327a. In those two cases, the emphasis is on the participation of the community in celebrating a festival, whereas, in the case of poiein in Thuc. 2.15.2, the emphasis is on the actual arranging or organizing of the festival. 


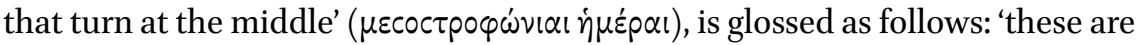
the days during which the people of Lesbos arrange (epitelein) a thysia that

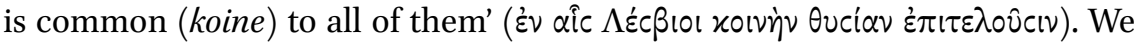
see here a seasonally recurring event of a sacrifice, which is at the core of the festival described in fragment 17 of Sappho-a festival that the Sons of Atreus themselves had 'arranged', as expressed by the word poiein 'make' at line 3 , when the two of them announced-in-prayer the performing of the very first such sacrifice. With regard to this usage of poiein 'make' in the context of 'arranging' a festival that centers on a sacrifice, an obvious semantic parallel comes to mind: in Latin, the verb facere can mean not only 'make' but also 'sacrifice', as we can see most clearly in the case of the derivative noun sacrificium 'sacrifice.' 43

The project of a prototypical sacrifice at Lesbos, as envisioned in fr. 17 of Sappho, would have required a great deal of effort, commensurate even with the earlier effort that went into the grand project of conquering Troy. In the case of that earlier effort, the Sons of Atreus had been faced with the megaloi aethloi

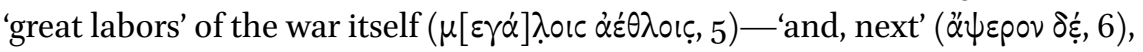
there was now the later effort, which was the arranging of a grand sacrifice at Lesbos-a sacrifice that was meant to make it possible for the Sons of Atreus to find the best way to achieve a successful homecoming. For the arrangement of such a sacrifice, an announcement-in-prayer would be needed. As I will argue, this prayer originally took place before the Sons of Atreus ever came to Lesbos, while they were still at Troy, but then there was an iteration of the prayer at the time of actually sacrificing one hundred cattle in the precinct of Hera at Lesbos.

As we see from the wording that survives in fr. 17 of Sappho, the Sons of Atreus needed to perform their prayer of supplication to Hera, Zeus, and Dionysus (9-10). And, in terms of my argument, their announcement-in-prayer was correlated with a sacrifice that became the foundation for the festival of Hera at Lesbos. According to the myth that is signaled in fr. 17 of Sappho, such a sacrifice, as announced in a prayer expressing a wish to find the best possible way to achieve a homecoming from Troy, became the foundational act for creating the festival of Hera as it is still celebrated in the present, when the speaking persona of Sappho must perform her own prayer of supplication to the goddess Hera (11).

It is in the context of this prayer in the present, as actually performed in fr. 17 of Sappho, that we can understand the announcement-in-prayer that was once performed by heroes in the heroic age. Once upon a time, according to

43 Benveniste (1973) part 6, sub-part 1. For the online version of this chapter, see http://chs .harvard.edu/CHS/article/display/3964. 
the myth, the Sons of Atreus needed to perform their prayer to Hera, Zeus, and Dionysus, in that order (again, 9-10), and, in their prayer, these conquerors of

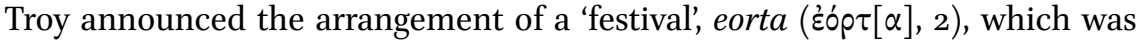
thus 'announced-in-prayer', arata ( $\dot{\alpha} \rho \dot{\alpha} \tau \alpha \nu, 3)$. And it is at this festival that the persona of Sappho is 'even now' praying to Hera, nyn de (again, 11). As Claude Calame observes, 'the temporal return of the heroic past to the present of the cult performance of the poem is ensured by the expression nyn $d e^{\prime 44}$ This expression is what I have just translated as 'even now' ( $\nu \hat{v} \delta \dot{\varepsilon}$..., 11).

\section{A 'Smoking Gun' in the Homeric Narrative}

For me the 'smoking gun' in the Homeric narrative about the sea voyages of Agamemnon and Menelaus after Troy in Odyssey 3 and 4 is an action taken by the goddess Hera. As said explicitly in Odyssey 4.512-513, Hera acts as the savior of Agamemnon in the course of his own final sea voyage. The salvation is temporary, since Agamemnon is killed after he makes his landing, but this salvation-at-sea is explicitly highlighted in the Odyssey. By contrast, the corresponding sea voyage of Menelaus fails to bring him back safe and sound to his homeland right away. The many detours experienced by Menelaus at sea are narrated in Odyssey 3 and 4. This contrast between success and failure in the sea voyages of the Sons of Atreus is correlated, I argue, with a contrast between a complete and an incomplete performance of a sacrifice to Hera at Lesbos. The successful sea voyage of Agamemnon matches his observance of the sacrifice, whereas the unsuccessful sea voyage of Menelaus matches a non-observance. Only the final phase of his sea voyage turned out to be successful for Menelaus. In the end, he succeeded because he finally got around to making a perfect sacrifice of one hundred cattle in Egypt (4.581-586).

The fact that the narrative of Odyssey 4 shows Hera as the savior of Agamemnon at sea signals a Lesbian origin for this part of the overall Homeric narrative- but only for this part. The other parts of the narrative are adjusted to fit other versions that originate not from Lesbos. A salient example is the fact that the savior of Nestor in Odyssey 4 is certainly not Hera but Poseidon, who is the principal divinity of the sea in the overarching Homeric narrative. That is why Nestor arranges for a sacrifice of bulls to Poseidon as his act of thanksgiving to that god for letting him sail safely from Lesbos to Euboea (178-179). 
I argue, then, that the role of Hera as a savior of Agamemnon at sea signals, exceptionally, the connection of the narrative in Odyssey 4 with the worship of Hera at Lesbos. And I must add that, from the new evidence of the Brothers Song, we can see clearly that Hera was worshipped in Lesbos as a divinity of the sea. In this song of Sappho, her persona speaks of praying to Hera by imploring the goddess to save her brother at sea-and to save also his ship and its cargo and thus even the wealth of his family (lines $5^{-6}[1-2], 9^{-13}\left[5^{-9}\right]$ ). And I highlight here the independent evidence showing that Hera was worshipped in her function as a divinity of the sea elsewhere as well in the Greek-speaking world. 45

\section{Praying Before Sacrificing}

A question remains: did Menelaus fail in the performance of a sacrifice at Lesbos? And, if so, did he fail also in the performance of the announcement-inprayer that came before the sacrifice? Here I consider two different explanations.

According to one explanation, Menelaus did indeed fail to perform such a prayer, and he did not attend the sacrifice of the hundred cattle, which would have been preceded by an introductory prayer.

As for an alternative explanation, which I prefer, it allows us to keep the reading of the text as transmitted in the papyrus. As I read fr. 17 of Sappho, Menelaus as well as Agamemnon did plan to make a sacrifice at Lesbos, and that is why we see at line 3 the plural form of the verb rọ́ncav 'they arranged', the direct object of which is the relative pronoun referring to the festival that was 'announced-in-prayer', $\alpha \rho \alpha \dot{\alpha} \alpha \nu$. In terms of the syntax, the subject of this

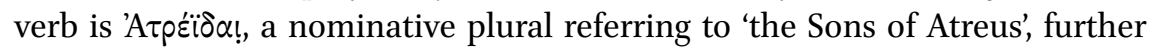
defined at line 4 as $\beta \alpha c^{\prime} \lambda \eta \varepsilon c$ 'kings' and then further described at line 5 as the achievers of great tasks like the capture of Troy. To my mind, this word for 'kings' must refer to Agamemnon and Menelaus together, who not only achieved the conquest of Troy together but then set out for Lesbos together: we can see this detail at line 7, where we read $\tau v^{\prime} \delta$ ' $\dot{\alpha} \pi \circ \rho \mu \dot{\alpha} \theta \varepsilon v[\tau \varepsilon c]$ 'having set forth to come here (tuide)'. So the two brothers must have planned together the sacrifice that led to the festival that is described as 'announced-in-prayer', $\alpha$ pó $\tau \alpha \nu$. When I say planned together I could also say wished together, in that the sacrifice was wished by the two of them together. But the problem was, the sacrifice was

45 See Pirenne-Delforge and Pironti (2014) 28, with reference to de Polignac (1997); see also Caciagli (2010) 236, and Boedeker, this volume. (This is note 61 in the longer version.) 
not performed by the two of them together. Earlier, I had said that 'wishingin-prayer' is the other side of 'announcing-in-prayer' as expressed by verbs like euchesthai and arasthai. And now we see that this two-sidedness of prayer can help explain why àpó $\tau \alpha \nu$ 'announced-in-prayer' both applies and does not apply to Menelaus: this hero wished that Hera would let him find the way for a safe homecoming, but he did not get to perform the final announcement-in-prayer that comes with the wish-in-prayer, since he did not get to participate in the sacrifice where the final announcement was made by Agamemnon. But the wish is there, and Menelaus surely participated in the wish expressed by way of the adjective $\alpha \rho \alpha \dot{\alpha} \tau \alpha \nu$ 'announced-in-prayer' that describes the festival that was 'made' by both brothers, according to this reading.

In terms of this explanation, there were at least two phases of the announcement-in-prayer here. First, the two Sons of Atreus jointly made the prayer when they were still at Troy, expressing their shared wish for a safe homecoming and at the same time making a commitment to the sacrifice that would be performed at Lesbos. But then, by the time the sacrifice was finally performed there, it was Agamemnon alone who performed it. And this sacrifice would have been introduced by a reiteration of the announcement-in-prayer that had originally been made at Troy. As I said before, following the formulation of Muellner, what you announce in prayer does not have to be a promise about the future: it can also be an announcement about the present or even about the past. And something that is wished for can be prayed for many times, as we see even from the contexts of poly-aratos, which I have so far translated simply as 'very much wished-for'. As we see from those contexts, we could also translate 'very often wished-for'.

\section{Choral Performance in the Precinct of Hera at Lesbos}

I now turn to the question: how are we to envision the performance of song at the festival founded by the Sons of Atreus? As I will argue, Sappho as the main speaker of fr. 17 is the main performer of such a song and, as such, she is speaking for all of Lesbos in the context of a grand sacrifice that replicates the hecatomb that had once been announced-in-prayer by the Sons of Atreus. And such a grand sacrifice is already anticipated, I argue, in the Brothers Song, where the speaking persona of Sappho refers to the procession that will lead to the precinct of Hera as the site of a choral performance that will celebrate the hecatomb.

I start by highlighting here a relevant detail that we find in the new evidence of the supplemented version of fr. 17 of Sappho and in the older evi- 
dence of fr. 13ob of Alcaeus: in both songs, the women of Lesbos made a ritual cry of ololyga 'ululation' in the context of celebrating the festival of Hera in the precinct of the goddess at Lesbos (Sappho 17.15 and Alcaeus 13ob.20). As I argued in my previous work on Alcaeus fr. 13ob, such ululation is an aspect of the choral performance of women who are participating in the festival. ${ }^{46}$ And I now add that the actual cry of ululation could signal a climactic moment in an overall choral performance. One such moment is when cattle are slaughtered at a sacrifice. A striking example is the description in Odyssey 3 of a bovine sacrifice arranged by Nestor at Pylos: at the moment when the slaughter actually takes place there, the womenfolk signal that moment by performing a ululation $(\dot{0} \lambda \dot{0} \lambda \nu \xi \alpha \nu, 450) .{ }^{47}$

I conclude, then, that the sacrifice to Hera that takes place in her precinct on the occasion of her festival in Lesbos is a hecatomb, that is, a sacrifice of one hundred cattle. It was this sacrifice that Agamemnon and Menelaus had vowed-in-prayer to perform for the first time, according to the myth retold in fr. 17 of Sappho.

And here I can come back full circle to a myth, originating from Argos, about the precinct of Hera at Argos. According to the myth, as retold in Dictys of Crete (1.16), it was inside this precinct that Agamemnon was chosen to lead the expedition to Troy. This formal beginning within the precinct of Hera, where the festival of the goddess was celebrated by the Argives, must have been a sacrifice, corresponding to the seasonally recurring thysia at the festival of Hera in Argos. As I have already shown, this word thysia refers to the festival itself, though its basic meaning is 'sacrifice'. At Argos, such a sacrifice is what was called a hecatomb, that is, the ritual slaughter of one hundred cattle. In the story as reflected in fr. 17 of Sappho, on the other hand, Agamemnon is inside the precinct of Hera at Lesbos, not at Argos. Together with Menelaus, Agamemnon had vowed-in-prayer to perform a hecatomb at Lesbos to signal a correct ending for the war by expressing a formal wish to find the best way home. But, in terms of my reconstruction (in the longer version of this essay as published online), Menelaus failed to arrive in time for the actual sacrifice.

$46 \quad$ Nagy (1993). For more on ululation as an aspect of choral performance by women, I refer to Bierl, this volume. (This is note 62 in the longer version.)

47 For still more on ritual ululations performed by women, see the seminal observations of Burkert (1983) 5, 12, 54 and (1985) 56, 72, 74. (This is note 63 in the longer version.) 


\section{Looking Back Diachronically at the Precinct of Hera}

In analyzing the aetiological myth that motivated the seasonally recurring festival of Hera at Lesbos, I have taken into account the evidence of the new textual supplements to fr. 17 of Sappho together with the evidence of indirect Homeric references to the festival in Odyssey 3 and 4. With this evidence in place, I now proceed to analyze diachronically the basics of what we now know about the venue for the festival, understanding that this venue was the precinct of Hera.

I start with the order in which the speaking persona in fr. 17 of Sappho names the three divinities: they were Hera herself, addressed as 'you' (9), and then Zeus (again, 9), and then Dionysus (10). These three divinities in fr. 17 of Sappho are the same three divinities whose sacred space is the temenos 'precinct' that we see pictured in fr. 129 of Alcaeus. The speaking persona in fr. 129, Alcaeus himself, is literally pointing to this temenos (129.2) with the deictic pronoun

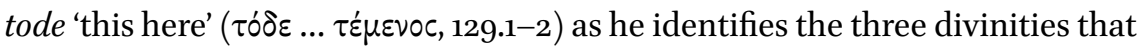
occupy the sacred space of this precinct:

1) The first divinity to be identified is Zeus, who is given here the epithet antiaos ( $\alpha v \tau i \alpha o v, 5)$, which is the same epithet we saw in fr. 17 of Sappho $\left(\Delta i^{\prime}\right.$ $\dot{\alpha} \nu \tau[i \alpha o v], 9)$. There I translated this epithet as 'lord of suppliants', and now we can see why such a translation applies: a scholion in the papyrus explains this word antiaos here in fr. 129 of Alcaeus as meaning hikesios (ix $\varepsilon$ ciov) which is a classical Greek epithet meaning 'receiving suppliants'.

2) The second divinity is 'the Aeolian goddess', who is addressed as 'you' by the speaking persona ( 'Aeolian goddess' must be Hera herself.

3) The third divinity is Dionysus (Zóvvuccov, 9), about whom the speaking persona speaks as 'this one here' ( $\tau o ́ v \delta \varepsilon, 8) .{ }^{48}$

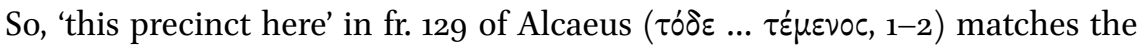
place signaled in fr. 17 of Sappho as the setting for a sacrifice once announcedin-prayer by Agamemnon and Menelaus. The prayer of the kings in fr. 17 had addressed the same three divinities, offering a supplication (9-10) by announcing-in-prayer (arasthai) a festival (eorta) to be held at this precinct (2), and the

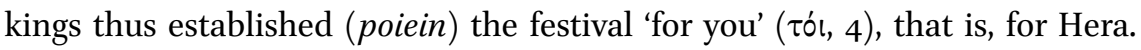

48 On the epithet omestes 'eating raw flesh' applied to Dionysus in fr. 129 of Alcaeus ( $\dot{\omega} \mu \dot{y}^{\prime} c \tau \alpha \nu$, 9), see Henrichs (1981). (This is note 64 in the longer version.) 
And, just as we saw in fr. 129 of Alcaeus, we see also here in fr. 17 of Sappho a deictic reference that ties the speaker-in this case, Sappho herself- to the place that Louis Robert identified as Messon in Lesbos: according to fr. 17 of Sappho, it was announced in heroic times that the festival of Hera should take place tuide 'here' ( $\tau v^{\prime} \delta \varepsilon, 7$ ). In this context, I draw attention to the fact that Hera, occupying her own place in the sacred space 'here', is addressed directly as 'you' by the speaking persona of Sappho ( $\tau$ ó, again, 4; also, at line 11: $c \hat{\varepsilon})$. And the eorta 'festival' of Hera is signaled as 'your' festival (cà ... żóp $\tau[\alpha], 2)$. As Claude Calame remarks, most incisively, about the use of the grammatical second person here in fr. 17 of Sappho, 'Hera is always present as you' 49

As the eternally present 'you' of the precinct, the identity of the goddess Hera subsumes even the identity of her consort, the god Zeus, who is in this context ranked after rather than before Hera in the Brothers Song. Zeus functions as the coefficient of Hera in bringing favorable winds for voyagers at sea (lines 13-20 [9-16]), and, in this role, he is described as basileus Olympo 'king of Olympus' ( $\beta \alpha c^{\prime} \lambda \varepsilon v$ ' $^{\prime} \mathrm{O} \lambda \dot{u} \mu \pi \omega, 17$ [13]). By now we can see that even this role of Zeus as basileus 'king' is subordinate to the role of Hera as basilea 'queen' (line 10 [6]). Here I return to the reference in fr. 130a of Alcaeus to the precinct of Hera as the teichos basileion ( $\tau \varepsilon i \chi x o c \beta \alpha c i \lambda \eta 10 v, 15$ ), glossed as 'Hera's wall' in an adjoining scholion ( $\left.\tau \dot{\imath} \tau \hat{\imath} c^{\prime \prime} \mathrm{H} \rho \alpha c\right)$. In the light of this gloss, I had already translated teichos basileion as 'the queenly wall', not 'the kingly wall'.

So, all aspects of Hera's precinct at Lesbos are understood primarily in terms of her omnipresence. Even more than that, the entire island of Lesbos belongs to Hera as its queen, and that is why, just as Zeus belongs to Hera as his queen, so also he belongs intimately to the landscape of her island. A case in point is the epithet of Zeus, basileus Olympo 'king of Olympus', in the Brothers Song ( $\beta a c^{\prime} \lambda \varepsilon v c^{\prime} \mathrm{O} \lambda \dot{v} \mu \pi \omega$, again, line 17 [13]). The fact is, this Olympus is a mountain local to Lesbos. It is situated to the south of Messon and to the west of Mytilene, and it is still called Olympus to this day (the Modern Greek name remains "O $\mathrm{\lambda} v \mu \pi \circ \mathrm{c})$. Unlike the Panhellenic Olympus of Homeric poetry, which is situated on the European mainland of Greece, this Olympus of Lesbos is part of an integrated local mythological landscape that fits the local ritual landscape of Hera's precinct.

I should add that the dyad of Hera and Zeus in the local mythology of Lesbos is a model of divine coefficiency, as we can see even from sources exterior to the songs of Sappho and Alcaeus. A shining example from the early Hellenistic era is a decree recorded in an inscription from the city of Mytilene in Lesbos, 
$S E G 36.75^{\circ}$, dated to the $330 \mathrm{BCE},{ }^{50}$ where we see that the goddess Hera was predominant among the gods of the city, since even her consort, Zeus himself, is qualified by way of the epithet Heraios, which means 'belonging to Hera' ( $\tau \hat{\omega}$ l $\Delta$ เ $\tau \hat{\omega} \iota$ 'H $\mid \rho \alpha i \omega \iota, 6-7) .{ }^{51}$

I turn next to the god Dionysus, third in the triad of divinities who figure in fr. 17 of Sappho (line 10). The relationship of this divinity with the dyad of Hera and Zeus is not clear at first glance, but, in this case as well, I see a pattern of syncretism where the status of Dionysus, like that of Zeus, is subordinated to the predominant status of Hera. A sign of such subordination, as I am about to argue, is the fact that the poetic language of Sappho and Alcaeus as spoken in the precinct of Hera actually integrates the idea of an omnipresent Hera with the idea of a selectively present Dionysus in moments of heightened emotion.

\section{Choral Performance by Girls and by Women and by Sappho Herself in the Precinct of Hera at Lesbos}

Now that I have considered the omnipresence of Hera as a 'you' in the precinct of the goddess at Lesbos, I turn to the 'we' who celebrate the festival of Hera on the occasion marked by fr. 17 of Sappho. Who are the 'we' here? My answer, in general, is that the 'we' stands for the people of Lesbos. More specifically, however, the 'we' in fr. 17 stands for both the speaking persona of Sappho and the attending ochlos 'throng' of parthenoi 'girls' together with gynaikes 'women' ([ó] $\left.\chi \lambda \circ \propto c \ldots \pi \alpha \rho \theta \varepsilon[\nu \omega \nu \ldots \gamma] \cup \nu \alpha i x \omega \nu, 13^{-15}\right)$. I see an imitation of this concept of ochlos 'throng' in the Ovidian Letter 15.199-202, referring to a turba 'throng' (202) of Lesbides 'Lesbian women' (199, 120, 121), described as nupturaque nuptaque proles 'soon-to-be-married and already-married offspring (of the island)' (202). I highlight, as a new piece of evidence, the wording I have just quoted from fr. 17 (13-15). We see here a collocation of the words for 'girls' and 'women', situated in a context where the persona of Sappho herself is speaking for all of them. In this role of speaking on behalf of all the women of Lesbos, Sappho is the lead singer of a choral performance at the festival of Hera within a space

$50 \quad$ The text is printed by Pirenne-Delforge and Pironti (2014) 28-30, with commentary. (This is note 66 in the longer version.)

$5^{1}$ I read with interest the commentary of Pirenne-Delforge and Pironti (2014) 30 on the syncretism of Zeus and Hera as reflected in the concept of Zeus Heraios. I would add that there is further evidence of such syncretism in Homeric poetry, as in the epithet of Zeus

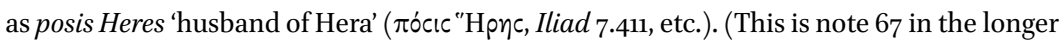
version.) 
that is evidently the precinct of the goddess. And, as I will argue, this choral performance represents, as it were, not only all the women but also all the people of Lesbos in general. Such is the role of the speaking 'we' of fr. 17.

The new piece of evidence, as I have just described it, concerning the participation of girls and women together with Sappho herself at the festival of Hera, can be used to counter an older interpretation of fr. 17, according to which this song did not necessarily refer to the festival of Hera as celebrated in the precinct of the goddess. ${ }^{52}$ In terms of this older interpretation, the speaking Sappho could have been referring only to girls who were present at the precinct, not to women. But now we see in the supplemented version of fr. 17 that the speaking persona of Sappho is in fact referring to the festival of Hera as celebrated in the precinct of the goddess. And now we see also that women as well as girls are pictured as participating in this festival of Hera. Further, the collocation of the word ochlos 'throng' with the words parthenoi 'girls' together with gynaikes

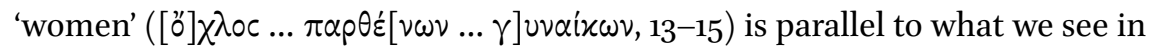
fr. 44 of Sappho describing a choral scene of celebration at the wedding of Hector and Andromache. In this song we see the collocation of ochlos 'throng' with

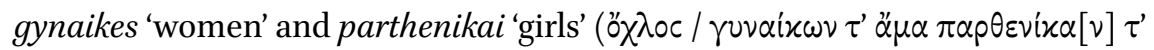
$\dot{\alpha} \pi[\alpha \lambda]$ oc $\varphi \dot{v} \rho \omega \nu, 14-15)$. Also, this song shows that the entire aggregate of women and girls, pais ochlos 'the entire throng', are participants in the celebration $(\pi \alpha \hat{i c}$ ó $\chi \lambda$ oc, 14). ${ }^{53}$

Here I return to fr. 129 and fr. $130 \mathrm{~b}$ of Alcaeus, referring to a temenos 'precinct' ( $\tau \dot{\mu} \mu \varepsilon v o c, 129.2$ and 13ob.13) that is xynon 'common' ( $\xi \hat{\jmath} v \circ v, 129.3$ ) to all the people of the island of Lesbos. As we have seen, fr. $130 \mathrm{~b}$ says that this precinct is sacred to three divinities: Zeus, Hera, and Dionysus (5-9). Evidently, then, the setting here is the same as the setting in fr. 17 of Sappho, which likewise shows that the precinct is sacred to these three divinities $\left(9^{-10}\right)$.

Further, in fr. 13ob of Alcaeus, we see a reference to Lesbiades 'women of Lesbos' $(\Lambda[\varepsilon<\beta i] \alpha \delta \varepsilon c, 17)$ who are explicitly described as gynaikes 'women' ( $\gamma u v \alpha i x \omega \nu, 19)$. According to the older interpretation that I just mentioned, this wording refers to an event involving only women at the precinct-and not to any event involving girls. In terms of this older interpretation, fr. 13ob of Alcaeus

\footnotetext{
$5^{2}$ For background, see Caciagli (2010) 239 and (2011) $155^{-156}$. (This is note 68 in the longer version.)

53 It may be that the actual groupings of women and girls are separate from each other in the rituals of participation. In fr. 17, I note the form $\dot{\alpha} \mu \varphi \iota c ̧[. .$.$] (line 16): as Leonard Muellner$ points out to me, this form may mean 'separately' here. I see a comparable situation in fr. 44, where the ritual actions of the daughters of Priam are signaled by the expression $\chi \hat{\omega}$ pıc $\delta$ ' $\alpha \hat{v}$ (line 16), meaning 'separately'. (This is note 69 in the longer version.)
} 
excludes girls just as fr. 17 of Sappho supposedly excluded women. But now we know, on the basis of the supplemented version of fr. 17, that the event to which fr. 17 refers does in fact include women as well as girls, and that this event is in fact the festival of Hera.

That said, I am ready to argue that fr. 13ob of Alcaeus, like fr. 17 of Sappho, is referring to a choral performance by the women of Lesbos at the festival of Hera that is being celebrated in the precinct of the goddess. Bruno Gentili had drawn attention to two words in this fr. 130b of Alcaeus that actually

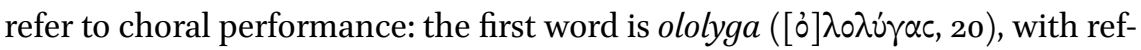
erence to the 'ululation' of the women of Lesbos, and the second word is the accompanying epithet ira 'sacred' ('p $\alpha[c], 20) .54 \mathrm{~A}$ third word that is relevant here in fr. 13ob of Alcaeus is another epithet that accompanies ololyga 'ululation': the ritual cry of the women of Lesbos is not only ira 'sacred' (ip $\rho[c]$, 20), it is also eniausia 'yearly' (Evvıvciac, again, 20). On the basis of these three words, we can see that the ritual described in fr. 13ob must have been a part of the seasonally recurring festival of Hera, featuring some kind of choral performance by the Lesbiades 'women of Lesbos', as indicated by the reference to 'the sacred seasonally-recurring ululation'. ${ }^{55}$ And now the new textual supplements for fr. 17 of Sappho show decisively that girls as well as women participated in choral performance at the festival of Hera. Moreover, these new supplements show also that the choral performance of the Lesbiades 'women of Lesbos', as they are called in fr. 13ob of Alcaeus, involves not only the girls and the women of Lesbos in general but also, even more important, the speaking persona of Sappho in particular. In fr. 17 of Sappho, as we can see in the light of the new textual supplements, this persona speaks for both the girls and the women of Lesbos.

The newly-supplemented evidence of fr. 17 of Sappho, showing the choral performance of girls and women and Sappho herself at the festival of Hera, fits what we already know from the wording of an anonymous poem in the Greek Anthology (9.189). This poem refers explicitly to a choral performance led by Sappho herself at the precinct of Hera in Lesbos. Sappho is pictured as the lead singer in a choros 'chorus' ( $\chi 0$ oóv, 3 ) of Lesbides 'women from Lesbos' ( $\Lambda \varepsilon c \beta i \delta \varepsilon c$, 2) who in turn are pictured as dancing inside a temenos 'precinct' sacred to the

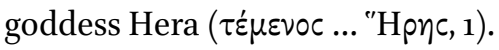

54 Gentili (1988) 220, 306 n. 30. In Nagy (1993) 222, I highlight the argumentation of Gentili. (This is note 70 in the longer version.)

55 Nagy (1993) 222-223. This argument is recapitulated in Nagy (2009/2010) 238. (This is note 71 in the longer version.) 
In my 1993 essay on fr. 129 and fr. 13ob of Alcaeus, 'Alcaeus in sacred space', I backed up the argument published in the 1960 article of Louis Robert concerning the points of reference that we read in the poem taken from the Anthology. ${ }^{56}$ Robert had connected the choral scene as described in that poem with a ritual event we see described in the scholia for Iliad 9.30: 'the people of Lesbos celebrate a beauty contest (agon) of women (gynaikes) in the precinct

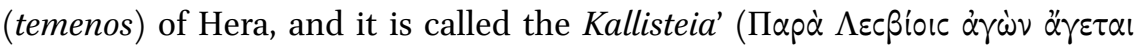

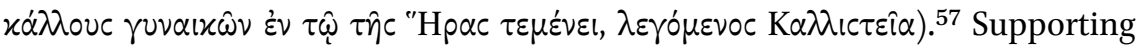
Robert, I argued that the ritual event of this 'beauty contest' at Lesbos was a kind of choral performance in its own right, matching the description of the choral performance in the poem taken from the Anthology. And now, on the basis of the new evidence supplementing the text of fr. 17 of Sappho, I argue further that both this beauty contest of the Kallisteia and the choral performance of the Lesbiades in fr. 13ob of Alcaeus were integral parts of one and the same festival of Hera in Lesbos.

In making this argument, I now consider yet another reference to such a beauty contest. In the dictionary of Hesychius (v. 3 p. 213 ed. Hansen), we find this entry: 'pylaiidees: this is the name for those who are judged (krinesthai)

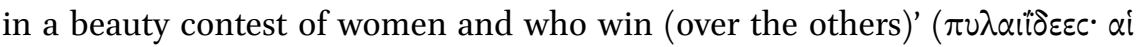

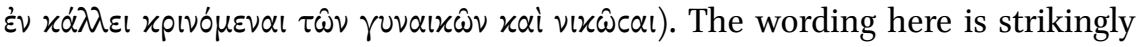
similar to the wording in fr. $13 \mathrm{ob}$ of Alcaeus, where the female participants in the choral performance taking place at the precinct of Hera are described as

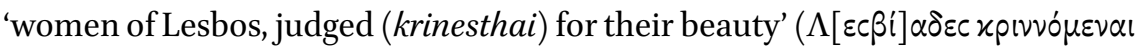

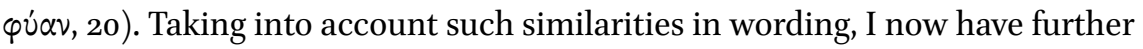
reason to argue that the beauty contest of the Kallisteia is a choral event, just as the performance of song and dance by Sappho together with her chorus of Lesbides in the poem taken from the Anthology is pictured as a choral event.

\section{A Diachronic View of Hera's Festival at Lesbos}

Essential for my argumentation here is the use of the word that refers to the festival of Hera in fr. 17 of Sappho, eorta ( $\dot{\varepsilon} \rho \tilde{\rho}[\alpha], 2)$. The same word for 'festival', in its Attic form heorte, is attested in another reference to the local custom of organizing beauty contests in Lesbos. The reference comes from Theophrastus, fr. 564 Fortenbaugh, as cited by Athenaeus 13.610a, where we

$56 \quad$ Nagy (1993) 222, with reference to Robert (196ob). (This is note 72 in the longer version.)

57 Nagy (1993) 222. (This is note 73 in the longer version.) 


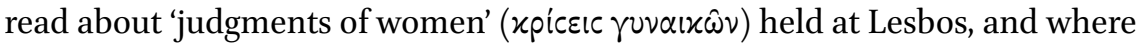

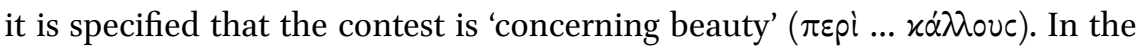
context of what is also said in Athenaeus 13.610a, which is the text that frames this reference from Theophrastus, other examples of such beauty contests are also cited, and it is made clear that the actual setting for these events is a heorte 'festival', as in the case of a seasonally recurring beauty contest held in honor of the goddess Demeter in Arcadia, highlighted in Athenaeus 13.61of ( $\dot{\varepsilon} \circ p \tau \hat{\eta})$.

Most remarkably, the reference from Theophrastus as cited by Athenaeus specifies that the observance of such a custom, where local women participate in a beauty context, is typical of two ancient Greek communities in particular. Besides highlighting the people of Lesbos as practitioners of beauty contests, the same report highlights, symmetrically, the people of Tenedos Athenaeus 13.610a: 'just as it (= the custom) is observed in the regions of the

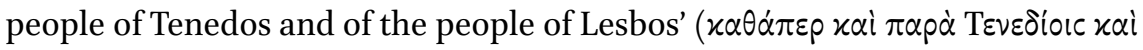
$\Lambda \varepsilon c \beta$ iolc).

Here it becomes vitally important for me to emphasize that the island of Tenedos, like the island of Lesbos, was an Aeolic community. For background, I now refer to a separate project that focuses on the Aeolic traditions of Tenedos. ${ }^{58}$ Here are two details that I highlight from that project. The first detail comes from the testimony of Strabo 13.1.32 and 13.1.46. As you travel south along the Asiatic coastline near Troy, passing a site named tò Achilleion, which means 'the place of Achilles', you come to a region named tò Achaiion, meaning 'the place of the Achaeans. ${ }^{59}$ This region, Strabo says, is the peraia of Tenedos, by which he means the part of a 'mainland' that belongs to an outlying island. In this case, the outlying island is Tenedos, and Strabo refers to the city of this island-state as a polis Aiolis 'Aeolian city', highlighting its two harbors and a shrine that is sacred to Apollo Smintheus (13.1.46).

The second detail comes from Pindar's Nemean 11, a song created for the praise of an aristocrat from the island of Tenedos. According to the song, this aristocrat was descended from ancestors who came from Amyklai with Orestes to settle Tenedos (34), and these settlers of the island are imagined as 'a bronze-

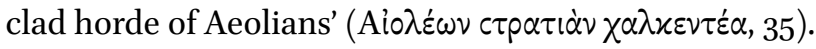

These two details about Tenedos, in view of the Aeolic traditions of this island, are relevant to the report we read from Theophrastus (again, fragment 564 as cited in Athenaeus 13.610a) concerning the parallelism between the

$5^{8} \quad$ Nagy $(2009 / 2010)$ 184-185. (This is note 74 in the longer version.)

59 Already at the first mention of Achaîion, Strabo combines the name with the article tò (13.1.32 C506; see also 13.1.46 C604, 13.1.47 C604). (This is note 75 in the longer version.) 
traditions of Tenedos and Lesbos in celebrating beauty contests for women. In view of the existing parallelism, I am ready to argue that the beauty contests held in Aeolic Tenedos were choral events, just as I argue that the beauty contests held in Aeolic Lesbos were choral events. Further, since the choral events at Lesbos were part of a festival that was aetiologized, as I argue, in a myth about a sacrifice arranged by the Achaeans when they visited the island of Lesbos, as mentioned in fr. 17 of Sappho, I can also argue for a parallel at Tenedos: there too, the beauty contests would have been choral events that were part of a festival that was aetiologized in a myth about a sacrifice arranged by the Achaeans when they visited the island of Tenedos. And such a pairing of aetiological narratives would correspond to the pairing of epic narratives in Odyssey 3 and Odyssey 4 about the visits of Achaean heroes to the Aeolic islands of Tenedos and Lesbos after their victory at Troy.

Ultimately, the Homeric narrative privileged the local myth of Aeolic Tenedos over the local myth of Aeolic Lesbos. In Odyssey 3, the grand sacrifice that took place after the conquest of Troy is localized at Tenedos (159). Only Menelaus participated in that sacrifice, while Agamemnon stayed behind at Troy in order to make his own separate sacrifice there and not at Tenedos. In terms of this version, evidently derivable from Tenedos, Agamemnon was planning to make his sacrifice to Athena at Troy. In terms of the version derivable from Lesbos, on the other hand, he was planning to make his sacrifice to Hera at Lesbos.

By contrast, in Odyssey 4, neither Agamemnon nor Menelaus is shown in the act of making any grand sacrifice that is localized at Lesbos, and the island is mentioned only in the context of accentuating, without explanation, the lateness of Menelaus in arriving at that island (168). This way, in terms of my argument, Homeric poetry slights the prestige of the grand sacrifice that was annually observed in the precinct of Hera at Lesbos-a prestige that continued to be recognized in fr. 17 of Sappho.

\section{A Synchronic View of Hera's Festival at Lesbos}

From a diachronic point of view, then, I have argued that the institution of beauty contests was in fact a traditional aspect of the festival of Hera as celebrated at her precinct in Lesbos. Accordingly, I think there is no reason to doubt that the word referring to the festival of Hera in fr. 17 of Sappho, eorta (źóp $\tau[\alpha], 2)$, signals a set of ritual events that includes the beauty contests of women. But there is likewise no reason to doubt that this same set of ritual events also includes the choral singing and dancing of girls. From a synchronic 
point of view, as we have already seen in the text of fr. 17, the word eorta signals the participation of girls as well as women in the celebration of Hera's festival.

And what unifies the roles of girls and women in the course of this celebration is the role of Sappho herself as the speaking persona who leads the choral singing and dancing. The clearest example is fr. 17. This song of Sappho, by way of her speaking persona, is presenting itself as a choral event. And, whether or not the girls and the women of Lesbos need to be pictured as performing separately from each other, the figure of Sappho remains the notional leader of the choral singing and dancing performed here by all the women of Lesbos, including the girls. Sappho is speaking for the female choruses of Lesbos, and these choruses are in turn speaking for all of Lesbos. As I noted already, I have ever since 1990 argued that Sappho is a choral personality. ${ }^{60}$ Such a personality, we now see, comes to life in the context of fr. 17 of Sappho, where the speaker is attending the festival of Hera as celebrated in the precinct of the goddess.

\section{Sappho, Alcaeus, and the Theology of Hera's Precinct at Lesbos}

Now that we understand more fully the importance of Hera in myths and rituals centering on the precinct of this goddess at Lesbos, I am ready to consider the 'theology' of this precinct - as reflected in the poetics of Sappho and Alcaeus considered together. When I say theology here, I mean the system of myths and rituals shared by the overall community that identifies with the precinct of Hera. And, when I say community, I mean what was meant in the songs attributed to Sappho and Alcaeus, where the precinct of Hera was notionally a common ground for the entire island of Lesbos.

To anticipate the kinds of misunderstandings that I expect to encounter, I must add here two qualifications, which are both formulated from a diachronic perspective:

1) When I say that the theology of the precinct of Hera at Lesbos is a system, I am keeping in mind the fact that any system changes over time, and that any changes in a system are conditioned by historical vicissitudes.

\footnotetext{
6o Again I cite Nagy (1990a) 370, with reference to Calame (1977) 367-377 (also 126-127). See now also Lardinois (1996) and the remarks of Calame (2009) 5. Also Ferrari (2014) 17. (This is note 76 in the longer version.)
} 
2) Just as the theology of Hera's precinct is a system, so also the poetics that generated the songs of Sappho and Alcaeus is a system. Further, just as the theology changes over time, so also this poetic system changes over time, and the changes are likewise conditioned by historical vicissitudes.

These two diachronic considerations affect what I have to say both about the theology of the precinct of Hera and about the poetics of Sappho and Alcaeus. My thesis is this: the theology and the poetics originally coexisted with each other, as systems, but they eventually had a parting of the ways. Originally, the theology of Hera's precinct, which Louis Robert succeeded in identifying as the sacred space called Messon, not only coexisted with the poetics of Sappho and Alcaeus: more than that, the theology originally interacted with the poetics.

When I say 'originally' here, I have in mind once again the conventional dating for the era of Sappho and Alcaeus, which as we already saw can be placed around 6оо вСE. As time went by, however, the system of poetics that we see at work in the songs of Sappho and Alcaeus broke free of its interactive theology as it started spreading, by way of poetic reception and transmission, beyond the historical context of Messon in Lesbos. By the time of Herodotus, who flourished in the second half of the fifth century ВСЕ, the reception and the transmission of songs attributed to Sappho and Alcaeus had already long ago extended to such diverse places as (1) the city of Athens, ${ }^{61}(2)$ the island state of Samos, ${ }^{62}$ and (3) the interpolitical Greek emporium of Naucratis in Egypt. ${ }^{63}$ In the venues of such diverse places, the poetic personae of Sappho

61 On the Athenian transmission of the songs of Sappho and Alcaeus, see Nagy (2007b) 218219, 226-227; also Nagy (2009c). (This is note 77 in the longer version.)

62 On the Samian transmission of the songs of Sappho and Alcaeus, see Nagy (2007b) 227232. (This is note 78 in the longer version.)

63 In another project, I plan to focus on the reception of the songs of Sappho at Naucratis, especially by way of Samos and Lesbos. On the roles of Samos and Lesbos (Mytilene) in the Hellenion at Naucratis, the primary source is Hdt. 2.178.2 (there is a useful commentary by Lloyd [2007] 373 on the importance of the Samian presence at Naucratis). In my project, I argue that the reportage of Herodotus (2.134-135) on the songs of Sappho about her brother's affair with the courtesan Doricha shows an awareness of such a reception. Also aware was Hecataeus, who is I am sure the missing link in what Herodotus says about the courtesan Rhodopis. The lore about this courtesan is evidently linked to Naucratis, and this lore is relevant to the reception of Sappho at Naucratis. Such a reception needs to be viewed in the context of ongoing traditions in the sympotic performance of Sappho's songs. In this regard, I think that the conflation of lore about Rhodopis and Doricha can be traced back to Hecataeus. Most relevant here is a reference we read in Athenaeus 9.410e 
and Alcaeus could break free of their original venue just as readily as the poetics of their songs broke free. I was saying earlier, for example, that Sappho's original songs, as performed chorally in the context of Hera's precinct at Lesbos, were later reperformed monodically at private symposia and at public concerts in Athens, and, as a result, Sappho could now be re-imagined as a sympotic or a concertizing performer of monody. ${ }^{64}$

After the theology and the poetics had a parting of the ways, the theology could continue to maintain its existence-now a separate existence-in the myths and rituals of Lesbos during the centuries that superseded the original era of coexistence between the theology and the poetics. On the basis of ongoing research concerning the myths and rituals connected with the precinct of Hera at Lesbos, we can see that the theology of this precinct lived on, and dynamically so, well into the Hellenistic era of Lesbos. I have already mentioned, as an example from the early Hellenistic era, a decree recorded in an

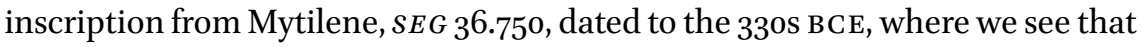
the goddess Hera was predominant among the gods of the city.

But such a separate existence of the theology as it continued to live on in Lesbos was not symmetrical with the separate existence of the songs of Sappho and Alcaeus, which had already found a new life outside of Lesbos. The theology of Lesbos could of course have no control any more over the songs of Sappho and Alcaeus. But such a loss of control would not stop the songs from pointing back to the old theology_-pointing back even to the old landmarks of the precinct of Hera as renewed markers for the here and now of an ongoing poetic imagination. If we consider Alcaeus, a perfect example of such pointing back is his fr. 13ob, where the speaking persona actually visualizes the choral performance of the women of Lesbos at the festival of Hera in the precinct of the goddess, highlighting their ritual cry of ululation, ololyga (line 20).

As I suggested in my essay 'Did Sappho and Alcaeus ever meet?', the visualization of such a choral event in fr. 13ob of Alcaeus is voiced by a speaking persona that is not only choral but also comastic, and such a comastic voice is connected with the worship of Dionysus. ${ }^{65}$ Here I return to the fact that Dionysus, along with Zeus, shares in the occupancy of Hera's precinct at Lesbos, as we see from the explicit wording of fr. 129 of Alcaeus (lines 1-9). Such a theological

to the remarks of Hecataeus ( $F G r H 1 \mathrm{~F} 35^{8}=$ test. 15b Fowler) about Sappho fr. 101. (This is note 79 in the longer version.)

64 More in Nagy (2007b); also Bierl (2010). (This is note 80 in the longer version.)

65 Nagy $(2007$ b) 215, with reference to a most helpful consultation with Anton Bierl (per litteras 2006.08.22), some of whose relevant observations I quote there. (This is note 81 in the longer version.) 
coexistence of Dionysus and Hera at the precinct of Hera corresponds, I argue, to the performative coexistence of comastic and choral voices as represented by Alcaeus and Sappho respectively. In the case of fr. $130 \mathrm{~b}$ of Alcaeus, for example, the voice of Alcaeus, speaking to his comrades in comastic performance, can simultaneously speak about a choral performance of local women in the context of one and the same festival that is being celebrated in one and the same precinct. Thus the context of comastic performance, which is sacred primarily to Dionysus, can be syncretistic with the context of choral performance, which is sacred primarily to Hera. And such performative syncretism is made possible by the theological syncretism of the precinct in which the performances take place.

In terms of such theological syncretism, I am now ready to argue that the poetic language of Sappho and Alcaeus, as spoken in the precinct of Hera, integrates the idea of an omnipresent Hera with the idea of a selectively present Dionysus in moments of heightened emotion. In the case of fr. $13 \mathrm{ob}$ of Alcaeus, for example, the comastic voice signals not only the presence of Dionysus but also the omnipresence of Hera-by way of pointing to the choral performance of the local women of Lesbos in the precinct of the goddess. And the speaking persona of Alcaeus in fr. $130 \mathrm{~b}$ is visualizing such a choral performance in a context where he, addressing his comrades in his own comastic voice, expresses his own highly emotional state of mind as a way of acknowledging most dramatically the presence of the god Dionysus. ${ }^{66}$

The presence of Dionysus comes alive not only in comastic performance. The god can cross over into choral performance, as when the persona of Sappho in fr. 1 speaks of her erotic passion as a kind of maenadic possession, describ-

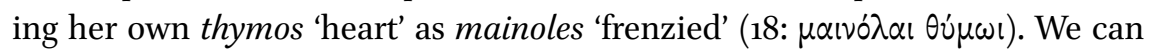
appreciate the heightened emotional effect in this context when we consider the fact that this word mainoles 'frenzied' was a ritual epithet of Dionysus (e.g. Cornutus, Theol. Gr. 60 Lang). ${ }^{67}$

66 As I argued in Nagy (1993) 223-225 (also Nagy [2009/2010] 237-238), the emotional selfdramatization of Alcaeus in fr. $130 \mathrm{ob}$ - as also in fr. 129 - is a function of his status as a cult hero who is imagined as speaking from the dead to his former comrades about future generations of women who are singing and dancing in choral performance to celebrate the goddess Hera in her precinct. Elsewhere too in archaic Greek poetry, as in Theognis 12091210, we see comparable situations where an alienated poet is imagined as speaking from the dead: see Nagy (1996) 212-213, with references to parallel situations in Celtic traditions. (This is note 82 in the longer version.)

67 See Nagy (2007b) 256-257. (This is note 83 in the longer version.) 


\section{The Power of Mimesis in the Songs of Sappho and Alcaeus}

The presence of such a Dionysiac theme in a song of Sappho shows that choral songmaking can actually make a mimesis of themes that belong to comastic songmaking. I am using the modern word mimesis here in the ancient sense of the Greek word mimesis, which simultaneously conveyed the primary idea of a dramatic 're-enactment' as well as the secondary idea of a mechanical 'imitation'. Relevant to these two meanings of mimesis is what I argued in an essay on the mimetic power of the chorus in general, as indicated by use of the verb mimeisthai 'make mimesis' in the Homeric Hymn to Apollo (163) with reference to a chorus of Delian Maidens, who figure as the local Muses of Delos, sacred island of Apollo. ${ }^{68}$

Conversely, as I have argued at length in 'Did Sappho and Alcaeus ever meet?', the comastic songs of Alcaeus can make a mimesis of themes that belong to the choral songs of Sappho. ${ }^{69}$ And such a pattern of mimesis only intensifies in a later era when the choral and the comastic songs of Sappho and Alcaeus respectively are transformed into monodic songs performed at private symposia and at public concerts. So, it should come as no surprise that we can find examples of monodic mimesis when we trace the reception of Sappho and Alcaeus forward in time, into the classical era of songmaking in fifth-century Athens. ${ }^{70}$

In the context of Athenian reception, I must add, the figures of Sappho and Alcaeus can now even 'meet' each other at symposia and at concerts, as we see when we consider a suggestively maenadic picture of the two of them interacting with each other in a simultaneously sympotic and concertizing duet performance: this picture of the pair graces one side of a red-figure vase of Athenian provenance, dating from around $480-470 \mathrm{BCE}$, while the other side features a symmetrical pairing of Dionysus and a maenad. ${ }^{71}$

68 Nagy (2013b). See also Peponi (2009). (This is note 84 in the longer version.)

$69 \quad$ Nagy $(2007 \mathrm{~b})$. At this point in my argumentation, I propose to correct a misunderstanding that might have been created, unintentionally, in the article of Caciagli (2010) 228 (n. 6) and 248 (n. 75): I need to put on record that I did not argue, in Nagy (2007b), that Sappho and Alcaeus personally 'met' at Messon in Lesbos. Such a 'meeting' is made possible, I argued, in the context of the reception that we can trace diachronically for the songs of Sappho and Alcaeus. (This is note 85 in the longer version.)

$70 \quad$ Again, Nagy (2007b). See also Nagy (2009/2010) 238 and Bierl (2010). (This is note 86 in the longer version.)

71 Munich, Antikensammlungen no. 2416; $A R V^{2} 385$ [228]; commentary in Nagy (2007b) 233237. On the iconography, see also Yatromanolakis (2007) $73-81$. (This is note 87 in the longer version.) 


\section{A Salient Example of Choral Mimesis in a Song of Sappho}

Moving backward in time, I now return to the original reception of Sappho and Alcaeus, which needs to be viewed in the context of Hera's precinct at Lesbos. In this context, as I have argued, the speaking voice of Sappho maintains a choral personality that is still actively engaged in the overall myths and rituals connected with the precinct. As I prepare to bring my essay to a close, I highlight one particular example where this choral personality asserts itself in a most salient way. The example comes from the Brothers Song of Sappho, where her speaking voice says that she needs to be sent off to pray to basilea

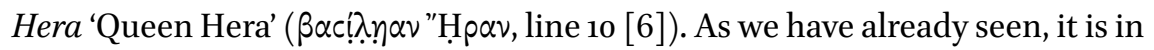
the precinct of Hera that Sappho will pray for the safe return of her brother Charaxos from his sea voyage. Even as she prays, as we have also seen, she is wishing that the brother is sailing his way back home (lines 11-12 [7-8]). In this personal moment, then, Sappho reveals her sisterly affection for her brother, despite all the frustrations. And such a self-revelation can be seen as a masterpiece of mimesis, where a choral voice re-enacts a personal experience.

But the experience of Sappho here in the Brothers Song is not only personal. It is also public. The whole song is staged as a choral performance, which is public, and the speaker will be speaking as a choral personality in the precinct of Hera, which is a public place that is notionally common to all the people of Lesbos. So the personal dimension of Sappho as a caring sister who retains her affection for her brother must be viewed together with her public dimension as a choral personality who speaks for the entire community in the sacred precinct of the goddess Hera. Both the personal and the public dimensions of Sappho are re-enacted in the mimesis of choral performance.

In brief, then, the emotions of Sappho as a sister in the Brothers Song are not only personal but also public, since her personal life is channeled by the poetics of choral performance, which is public. This is what I had meant when I chose the wording a poetics of sisterly affect in the title of my essay.

\section{The Name of Sappho}

The poetics of sisterly affect are so deeply rooted in the songs of Sappho that even her identity as a choral personality is shaped by such poetics. I say this because the name of Sappho seems to be a function of her poetic role as a sister. On the basis of linguistic evidence concerning the form Sappho, I propose that her name is derived from a word that actually means 'sister'. And, in line with my argument about the poetics of sisterly affect in the songs of Sappho, I 
propose further that this word for 'sister' is a term of affection, a baby word that derives from affectionate baby talk. ${ }^{72}$

I start by considering a pattern of alternation, attested in Greek epigraphical texts stemming from the Roman era, in the formation of names given to women. My point of reference is the name Sappho, which I consider here in contexts where the naming apparently has nothing to do with the famous Sappho. ${ }^{73}$ For example, we find a name like Aurelia Sappho $\left(\mathrm{A} \dot{p} \eta \lambda \lambda^{\prime} \alpha \mathrm{C} \alpha \pi \varphi \omega^{\prime}\right)^{74}$

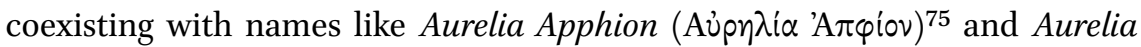

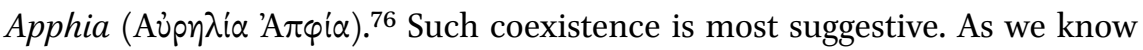
from the Greek lexicographical tradition, the noun apphion ( $\dot{\alpha} \pi \varphi$ iov) is a neuter diminutive variant of the onomatopoetic form appha $(\dot{\alpha} \pi \varphi \alpha)$, which means 'sister'.77 Clearly, both appha ( $\ddot{\alpha} \pi \varphi \alpha)$ and apphion ( $\dot{\alpha} \pi \varphi$ iov) are onomatopoetic baby words, meaning something like 'little girl. ${ }^{78}$ Another derivative of appha $(\ddot{\alpha} \pi \varphi \alpha)$ is apphia $(\dot{\alpha} \pi \varphi i \alpha)$, which can be explained as a feminine adjective. So, we can see that the names Apphion ('A $\pi \varphi i o v)$ and Apphia ('A $\pi \varphi i \alpha)$ are based on these baby words apphion ( $\dot{\alpha} \pi \varphi \hat{i} o v)$ and apphia ( $\dot{\alpha} \pi \varphi \dot{i} \alpha)$ respectively. And such baby words can apply not only to sisters in particular but also to beloved little girls in general—or even to beloved women. For example, the words apphion ( $\dot{\alpha} \pi \dot{i} 0 v)$ and apphia $(\dot{\alpha} \pi \varphi i \alpha)$ are both explained by lexicographers as hypokorismata 'terms of endearment' ( $\dot{\pi}$ тoxopic $\mu \alpha \tau \alpha$ ) referring to a 'young mistress of the household' ( $\left(\varepsilon_{\alpha} \alpha c \delta \varepsilon c \pi \sigma^{\prime}(\nu \eta c) .{ }^{79}\right.$ Another traditional way of defining the diminu-

72 I use the expression baby word as a parallel to the expression Lallwort as used by Zuntz (1951), who considers and then rejects the possibility that Sappho is a Lallname. Although there is no proof, he thinks that this name Sappho originated from some non-Greek language of Asia Minor (this theory is noted by Caciagli [2011] 271), and that this particular language had an initial s- (as in Sappho) that was not pronounced the same way as was Greek initial c-. I am grateful to Timothy Barnes for sharing with me his impressions of this learned article by Zuntz. For more on word play in Sappho, see Nagy (2009b) 69-72. (This is note 88 in the longer version.)

73 Besides the examples that I am about to show, there are also other such attestations, e.g. SEG 39.840. (This is note 89 in the longer version.)

74 E.g., IG XII.4 (Paton-Hicks 141); also I. Leukopetra 45, 47, 83. (This is note 90 in the longer version.)

75 E.g., IG XII.4 (Inscr. di Cos [Fun.] EF 308); also TAM 199. (This is note 91 in the longer version.)

76 E.g., Ephesos 2221; also SEG 57.1494. (This is note 92 in the longer version.)

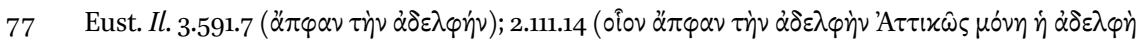

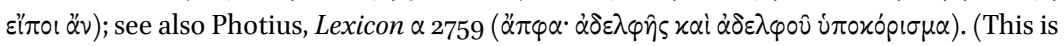
note 93 in the longer version.)

$78 \quad D E L G$ s.v. $\ddot{\alpha} \pi \varphi \alpha$. (This is note 94 in the longer version.)

79 Pollux, Onomasticon 3.74.3. (This is note 95 in the longer version.) 
tive apphion ( $\left.\dot{\alpha} \pi \varphi i^{\circ} \mathrm{v}\right)$ is to say that it is a hypokorisma 'term of endearment'

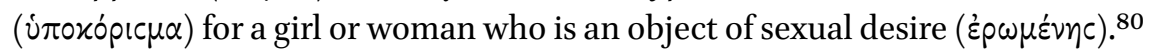
Lastly, the word appho $\left(\dot{\alpha} \pi \varphi \omega^{\prime}\right)$, morphologically symmetrical with the name Sappho $\left(\mathrm{C} \alpha \pi \varphi \omega^{\prime}\right)$, is explained by lexicographers as another word for 'sister'.81

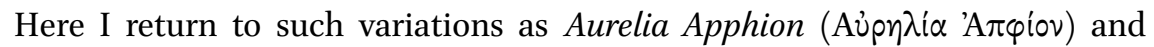

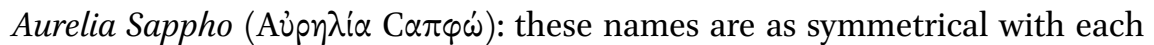
other as are the nouns apphion ( $\dot{\alpha} \pi \varphi \hat{i} \sigma v)$ and appho $\left(\dot{\alpha} \pi \varphi \dot{\omega}^{\prime}\right)$, both of which could mean 'sister'.

What is still missing in this set of linguistic evidence is a common noun shaped *sappho ( ${ }^{*} c \alpha \pi \varphi \omega$ ), which would mean 'sister'. (When I say common noun here, I mean a noun that is not a name, as opposed to a proper noun, which is a name.) In the case of a proper noun like Apphion ('A $\pi \varphi$ iov), however, we know for sure that it is based on the neuter diminutive common noun apphion ( $\alpha \pi \varphi$ iov), meaning little sister' or 'little girl'. So, I am ready to argue that the proper noun Sappho (C $\left.\alpha \pi \varphi \omega^{\prime}\right)$ was likewise based on a similar common noun *sappho ( ${ }^{*} c \alpha \pi \varphi \omega$ ), so far unattested, which would be a variant of the attested common noun appho ( $\dot{\alpha} \pi \varphi \dot{\omega})$, meaning 'sister'.

But the question remains: why is the form Sappho $\left(\mathrm{C} \alpha \pi \varphi \omega^{\prime}\right)$ attested only as a proper noun? My answer is that the form Sappho (C $\left.\alpha \pi \varphi \omega^{\prime}\right)$ survived phonologically as a proper noun only because it was a functional variant of another proper noun, Psappho ( $\left.\Psi \alpha \pi \varphi \omega^{\prime}\right)$, which is attested as a variant form of Sappho $\left(\mathrm{C} \alpha \pi \varphi \omega^{\prime}\right)$ in the textual tradition of Sappho. If Sappho (C $\left.\alpha \pi \varphi \omega^{\prime}\right)$ had not been a functional variant of Psappho ( $\left.\Psi \alpha \pi \varphi \omega^{\prime}\right)$, it would have become Appho ( $\left.{ }^{*} A \pi \varphi \omega^{\prime}\right)$ at an early stage in the history of the Greek language when word-initial $s$ - (as in *s-appho) became $h$ - (as in * $h$-appho), which in turn became simply a glottal stop (as in -appho) by way of 'psilosis'. I propose, then, that the form Psappho was in fact a playfully affectionate phonetic variant of the form Sappho. The variation of Psappho / Sappho ( $\Psi \alpha \pi \varphi \omega^{\prime}$ / C $\left.\alpha \pi \varphi \omega^{\prime}\right)$ is comparable to such variations as psitta / sitta $(\psi i \tau \tau \alpha /$ ci $\tau \tau \alpha)$, which are onomatopoetic calls. ${ }^{82} \mathrm{We}$

$80 \quad$ Eust. Il. 2.111.17 and 3.591.7. (This is note 96 in the longer version.)

81 Didymus Caecus (Migne [1857-1866] vol. 39, p. 656, line 5). (This is note 97 in the longer version.)

82 This onomatopoetic alternation $p$ sitta / sitta ( $\psi i \tau \tau \alpha /$ ci $\tau \tau \alpha)$ is mentioned by Zuntz ([1951] 17 n. 31), who compares the modern alternation psst! / sst! — but who in the end rejects the relevance of such examples to the alternation Psappho / Sappho. Olga Levaniouk has found another example of such onomatopoetic alternation: in the dictionary of Hesychius under the entry sellizesthai, we see an equation being made with psellizesthai ( $\sigma \varepsilon \lambda \lambda i \zeta \varepsilon \sigma \theta \alpha \mathrm{l}$ I $\psi \varepsilon \lambda \lambda i \zeta \varepsilon \sigma \theta \alpha \mathrm{l})$. The attested meanings of both these words show clearly that they derive from the onomatopoetics of baby talk. For example, Aristotle explicitly uses the word 
read in the Onomasticon of Pollux (9.122.3, 9.127.1) that psitta Maliades psitta

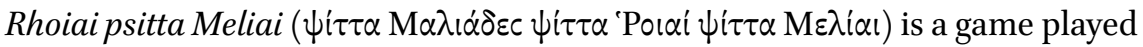
by parthenoi 'girls' as distinct from gynaikes 'women'. According to Pollux, the Maliades and Rhoiai and Meliai are nymphs, and girls call out their names, punctuated by the intervening calls of $p s i t t a$, in footraces that they run, urging each other to speed ahead. Also, in Theocritus 8.69, a herdsman calls out

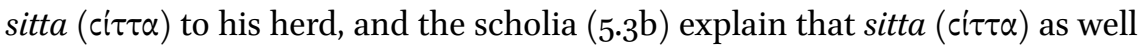
as a variant form psitta $(\psi i \tau \tau \alpha)$ is a sound made by a herdsman when he calls out to his herd.

The point is, just as the variant form psitta ( $\psi i \tau \tau \alpha)$ prevents, by analogy, a phonological change in the variant form sitta (ci $\tau \tau \alpha)$, which would otherwise be expected to change from sitta (ci $\tau \tau \alpha)$ to ${ }^{*}$ hitta ( $\left.{ }^{*} i \tau \tau \alpha\right)$ to ${ }^{*} i t t a\left({ }^{*} i \tau \tau \alpha\right)$, so also the variant Psappho ( $\left.\Psi \alpha \pi \varphi \omega^{\prime}\right)$ prevents, again by analogy, a phonological change in the variant Sappho $\left(\mathrm{C} \alpha \pi \varphi \omega^{\prime}\right)$, which would otherwise be expected to change from *sappho ( $\left.{ }^{*} c \alpha \pi \varphi \omega^{\prime}\right)$ to ${ }^{*} h a p p h o\left({ }^{*} \dot{\alpha} \pi \varphi \dot{\omega}^{\prime}\right)$ to appho $\left(\dot{\alpha} \pi \varphi \omega^{\prime}\right)$ in the case of common nouns-but not in the case of hypocoristic names where the alternation of Psappho / Sappho ( $\Psi \alpha \pi \varphi \omega^{\prime}$ / C $\left.\alpha \pi \varphi \omega^{\prime}\right)$ is maintained. ${ }^{83}$

I conclude, then, that the name Sappho, like the names Apphion and Apphia, was originally an onomatopoetic baby word derived from terms of endearment addressed to a sister. For an interesting parallel in English usage, as attested in some regions of the United States, I point to such women's names as Sissy, even Sister.

In the case of ordinary women who happened to be called Sappho in the Greek-speaking world, there would be of course nothing extraordinary about their name if it really meant 'Sister'. Such a meaning becomes extraordinary, however, when we find it embedded in the poetics of a choral personality who, once upon a time, called herself by the name of 'Sappho'. Hers was an extraordinary persona who could speak to all the people of Lesbos, unveiling her sisterly affections just as memorably as she veiled her womanly desires.

psellizesthai in referring to childish speech patterns (Historia animalium $536 \mathrm{~b} 8$ ). (This is note 98 in the longer version.)

83 In the case of the form Psappho ( $\left.\Psi \alpha \varphi \varphi \omega^{\prime}\right)$, which reflects the spelling that survives in the textual tradition of Sappho, we might have expected some kind of formulaic alternation with the form Sappho (C $\left.\alpha \pi \varphi \omega^{\prime}\right)$. Within the system of Aeolic songmaking, the placement of Sappho might have been needed after short word-final vowels in order to avoid 'making position', whereas Psappho could be used wherever there was no need to avoid 'making position'. (This is note 99 in the longer version.) 